\title{
Growth and collapse of a deeply eroded orogen: Insights from structural, geophysical, and geochronological constraints on the Pan-African evolution of NE Mozambique
}

\author{
G. Viola, ${ }^{1}$ I. H. C. Henderson, ${ }^{1}$ B. Bingen, ${ }^{1}$ R. J. Thomas, ${ }^{2}$ M. A. Smethurst, ${ }^{1}$ \\ and S. de Azavedo ${ }^{3}$ \\ Received 26 February 2008; revised 5 June 2008; accepted 9 July 2008; published 15 October 2008.
}

[1] This paper presents results of a large multidiciplinary geological mapping project in NE Mozambique, with a focus on the structural evolution of this part of the East African Orogen (EAO). It integrates field structural studies with geophysical interpretations and presents new geochronological data. The tectonic architecture of NE Mozambique can be subdivided into five megatectonic units on the basis of lithology, structure and geochronology: unit 1, Paleoproterozoic Ponta Messuli Complex in the extreme NW corner of NE Mozambique, which represents the local NW foreland to the EAO; unit 2, a collage of Mesoproterozoic metamorphic complexes, which forms the basement to unit 3, a stack of Neoproterozoic, NW directed imbricate thrust nappes named here the "Cabo Delgado Nappe Complex" (CDNC); unit 4, restricted Neoproterozoic metasedimentary basins; and unit 5, two exotic Neoproterozoic granulite mélange complexes. The units were assembled during a long and complex history of NW directed shortening, which commenced with nappe stacking and emplacement of the CDNC over the Mesoproterozoic basement terranes toward the NW foreland. It is proposed that the CDNC and the Eastern Granulites farther north in Tanzania are remnants of Neoproterozoic volcanic arcs and microcontinents formed "outboard" of the Mesoproterozoic continent after $596 \pm 11$ Ma. Field and potential field geophysical data show that the nappes were folded by regional-scale NE-SW trending folds that formed in response to a later stage of the same shortening episode and this episode gave rise to the Lurio Belt, a prominent structural feature of northern Mozambique and a key element (often as suture zone) in many Gondwana reconstructions. The Lurio Belt is here interpreted as a structure generated during folding of the CDNC during later stages of the progressive shortening event. It is, however, a

\footnotetext{
${ }^{1}$ Geological Survey of Norway, Trondheim, Norway.

${ }^{2}$ British Geological Survey, Keyworth, UK.

${ }^{3}$ National Directorate of Geology of Mozambique, Nampula, Mozambique.

Copyright 2008 by the American Geophysical Union. 0278-7407/08/2008TC002284
}

repeatedly reactivated shear zone, probably at the site of an older (Mesoproterozoic?) discontinuity, with an intense pure shear deformation history. It is cored by strongly attenuated lenses of a granulitic tectonic mélange, the Ocua Complex (megatectonic unit 5) and is intruded by Late Pan-African granitoids of the Malema Suite. The compressional phase of the orogen was postdated by NW-SE directed extension. New $\mathrm{U}-\mathrm{Pb}$ zircon and monazite dates show that extension was initiated at circa $540 \mathrm{Ma}$ in the eastern Lurio Belt. It is argued that extension was the result of a major episode of orogenic collapse of the EAO, initiated by gravitational instabilities resulting from crustal thickening during the shortening phase. Citation: Viola, G., I. H. C. Henderson, B. Bingen, R. J. Thomas, M. A. Smethurst, and S. de Azavedo (2008), Growth and collapse of a deeply eroded orogen: Insights from structural, geophysical, and geochronological constraints on the Pan-African evolution of NE Mozambique, Tectonics, 27, TC5009, doi:10.1029/2008TC002284.

\section{Introduction}

[2] The term "Pan-African" is widely used to refer to the central part (largely in Africa) of the global orogeny that resulted in the formation of the supercontinent Gondwana between Late Neoproterozoic and Cambrian times [e.g., Unrug, 1997]. Although there is general consensus on the first-order geological features of Gondwana, there is ongoing debate about the number, timing, duration, geometry and kinematics of the individual collisions that led to this spectacular and complex continental assembly (see, for example, discussion by Meert [2003, and references therein]). This debate impacts not only on the understanding of the Pan-African events themselves, but also on models of the earlier, and thus more obscure, tectonic and geodynamic history of the component crustal fragments of Gondwana and issues such as the definition of the Mesoproterozoic supercontinent of Rodinia.

[3] Recently, much research has specifically focused on locating the final collision zone sutures between East and West Gondwana, represented by the Pan-African East African-Antarctic Orogen (EAO) [e.g., Stern, 1994] and on establishing a realistic and consistent plate configuration for the final assembly. The EAO runs approximately $\mathrm{N}-\mathrm{S}$ along the eastern margin of the African continent (Figure 1a) 
and is generally interpreted as a complex zone of arccontinent and continent-continent collision. Recent original and review articles have summarized a wealth of ideas on its geological and tectonic evolution [e.g., Bauer et al., 2003; Grantham et al., 2003; Hanson, 2003; Harley, 2003; Johnson and Woldehaimanot, 2003; Meert, 2003; Yoshida et al., 2003; Jacobs and Thomas, 2004; Collins and Pisarevsky, 2005; Johnson et al., 2005; Grantham et al., 2008]. Difficulties in unravelling all aspects of the evolution of the orogen stem generally from the paucity of traditional geological "tools," such as present-day seismicity, robust stratigraphic correlations, regional structural schemes, geomorphological analysis, etc., which hampers straightforward reconstruction of tectonic events in space and time. An improved understanding can therefore only be obtained from an integrated regional-scale approach that relies on tectonostratigraphy, structural geology, geochronology, petrology and geophysics.

[4] The bedrock geology of NE Mozambique has recently been investigated as part of an infrastructure development program funded by the World Bank and other donors [Norconsult Consortium, 2007a]. The 5 year program involved reconnaissance geological mapping at the 1:250,000 scale over 31 degree square sheets, acquisition of structural, petrographic, mineralogical, geochemical and geochronological data, a regional airborne aeromagnetic and radiometric geophysical survey and the establishment of the mineral resources potential of the area. This initiative offered a unique opportunity to investigate the nature and tectonic evolution of a relatively large sector of the EAO by means of a large-scale, integrated multidisciplinary approach.

[5] The study area is situated at a critical central location in the Gondwana puzzle, arguably at the intersection of four Pan-African belts, namely (Figure 1a), (1) the N-S trending EAO, extending from NE Mozambique to Arabia, including the "Mozambique Belt" of Holmes [1951] and the ArabianNubian Shield; (2) the E-W trending Zambezi Belt, possibly linked to the Damara Belt of Namibia via the Lufillian Arc [Johnson et al., 2007]; (3) the N-S trending Dronning Maud Province in East Antarctica, and (4) the LützowHolm Complex in Antarctica, possibly linked eastward with the Prydz Bay Belt and to the Eastern Ghats in India.

[6] Available geotectonic models for NE Mozambique were largely calibrated using Rb-Sr geochronological data [e.g., Pinna et al., 1993]. These models gave contrasting, and sometimes conflicting, interpretations as to the relative importance of the two main orogenic events recorded in the region, namely the late Mesoproterozoic to early Neoproterozoic $(1.2-0.9 \mathrm{Ga})$ crust-forming orogenic cycle (vari- ably known in the literature as "Mozambican" or "Lurian" (in Mozambique), "Namaquan" (in South Africa), "Kibaran" or "Irumide" (in Central Africa) or "Grenvillian" (in North America)), and the later circa 0.6-0.5 Ga PanAfrican orogeny [e.g., Holmes, 1951; Jourde and Vialette, 1980; Sacchi et al., 1984; Cadoppi et al., 1987; Costa et al., 1992; Pinna et al., 1993; Costa et al., 1994; Stern, 1994; Pinna, 1995; Kröner et al., 1997; Sacchi et al., 2000]. However, more recent data from NE Mozambique and the contiguous crust in Malawi and Tanzania along with the results of the recent mapping program [e.g., Kröner, 2001; Jamal, 2005; Norconsult Consortium, 2007a; Engvik et al., 2007] leave no doubt that the present-day large-scale crustal architecture in the study area is predominantly the product of the Pan-African orogeny, during which the lithotectonic units exposed in NE Mozambique were assembled, deformed, and metamorphosed. Indeed, Pan-African overprinting is so pervasive that it is difficult to unravel and describe the pre-Pan-African history with any degree of confidence.

[7] In this paper we report new field structural observations and integrate them in a large-scale tectonic analysis supported by new high-resolution aeromagnetic and radiometric surveys. Two new U-Pb zircon dates of critical lithologies are presented. Particular attention is paid to the structural development of the Lurio Belt, the most prominent structural feature in the area, though this represents only a small part of the complex development of the region. With these data we attempt to erect a consistent temporal sequence of tectonic events, based on absolute geochronological constraints, field geometric and kinematic characteristics and crosscutting relationships. Finally, our aim is to outline and discuss a comprehensive model for the regional tectonometamorphic evolution of NE Mozambique during Pan-African times and to explore the possible implications for large-scale plate reconstructions.

\section{Regional Geological Overview}

[8] A convenient way to illustrate the complex structural and tectonic framework of the study area is by reference to the sketch tectonostratigraphy presented in Figure $1 \mathrm{~b}$ and as a map in Figure 1c, which portrays the geographic distribution of the geological complexes/terranes defined during the mapping program. Detailed lithological, geochronological and geochemical descriptions of each lithotectonic unit and a rationale for the newly established tectonostratigraphy of NE Mozambique are reported by Norconsult Consortium [2007a].

Figure 1. (a) Reconstruction of Gondwana showing the extent of the main Pan-African mobile belts, following Meert [2003]. The red rectangle shows the location of the study area at the core of the supercontinent puzzle. ANS, ArabianNubian Shield; DB, Damara Belt; DMP, Dronning Maud Province; EG, Eastern Ghats; LA, Lufillian Arc; LHC, LützowHolm Complex; MB, Mozambique Belt; PBB, Prydz Bay Belt; ZB, Zambezi Belt. (b) New tectonostratigraphic column for northern Mozambique. Paleoproterozoic crust forms megaunit 1, Mesoproterozoic crust forms megaunit 2, Neoproterozoic "far-traveled" nappes (part of the newly defined "Cabo Delgado Nappe Complex") are megaunit 3. Attribution of the Txitonga Group to the Neoproterozoic cover or to the far-traveled nappe system remains a matter of debate. (c) Complex/ terrane map of the entire area mapped during this project. Squares are $1^{\circ}$. 

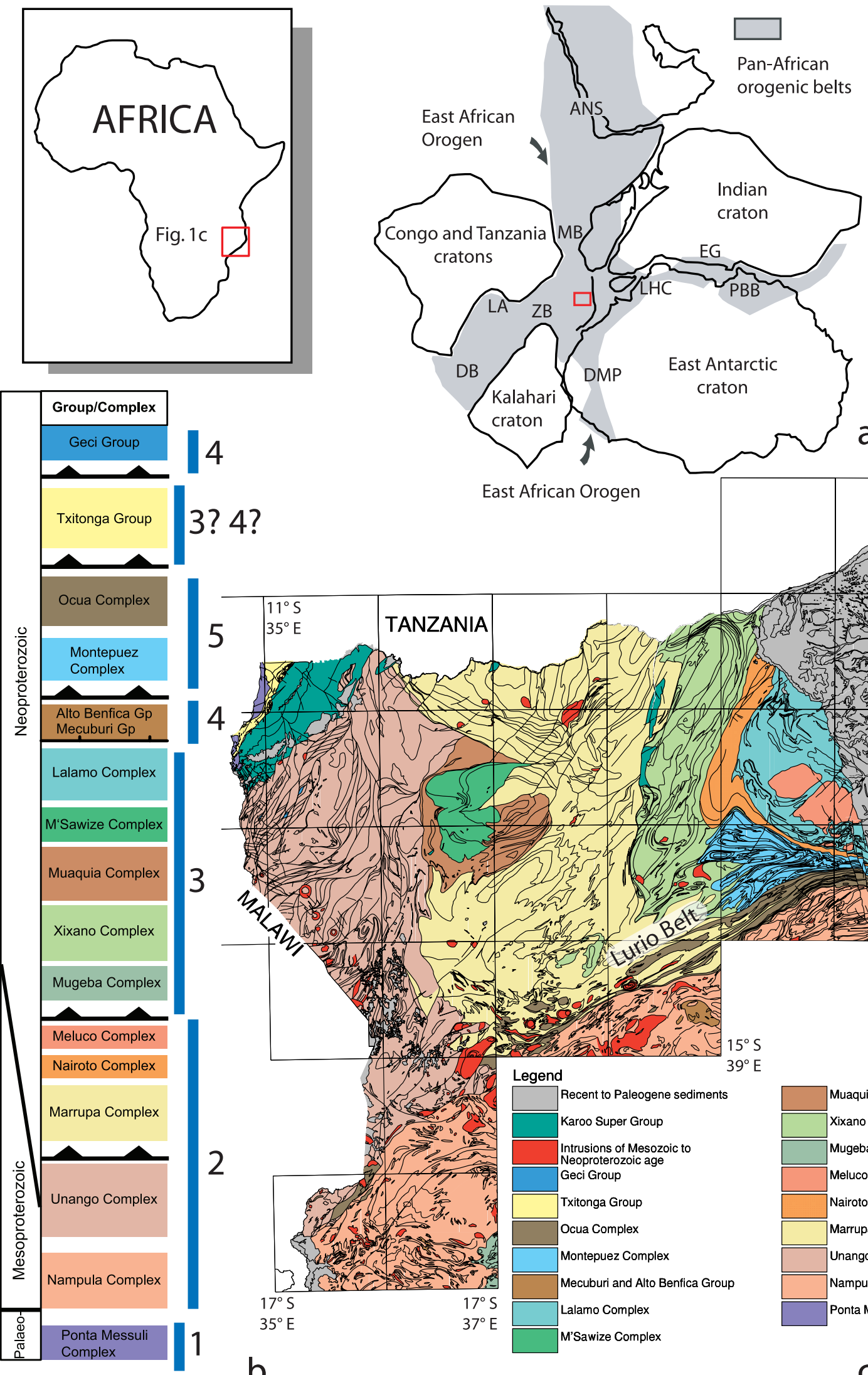

$3 ? 4 ?$

East African Orogen

a
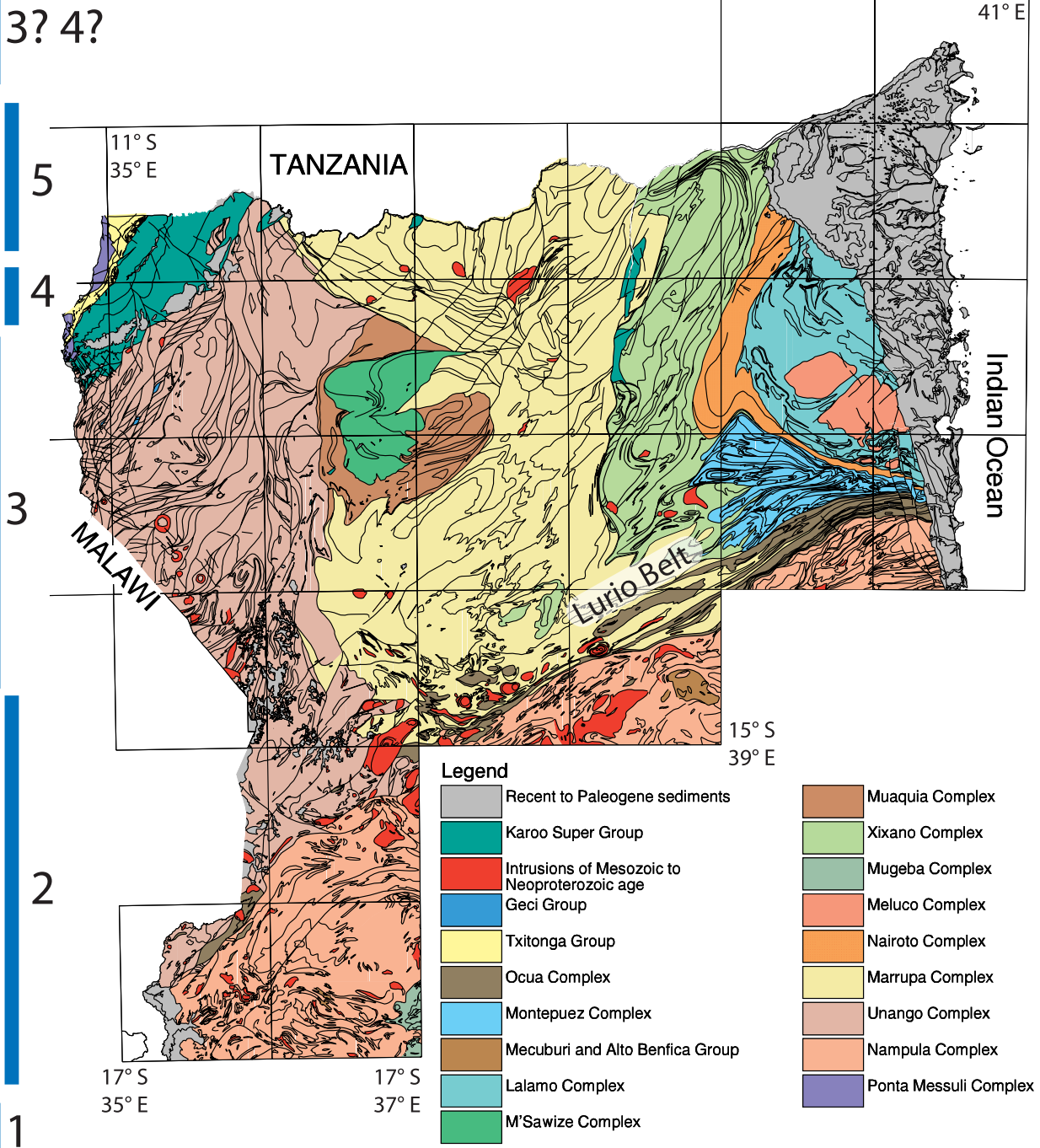

b

Figure 1 
[9] Geological complexes in NE Mozambique can be separated into five major, genetically distinct, megatectonic units, which, from the structurally lowest to the highest, are (Figures 1b and 1c) (1) a Paleoproterozoic domain, the Ponta Messuli Complex, which forms the NW foreland of the Pan-African orogen (it contains migmatitic paragneisses, augen gneisses, talc schists, and amphibolites); (2) an extensive Mesoproterozoic gneiss domain, the Nampula, Unango, Marrupa, Nairoto, and Meluco complexes, which was reworked and transported during the Pan-African orogeny (characterized predominantly by granitic, granodioritic, tonalitic, and banded migmatitic gneisses); (3) a dominantly Neoproterozoic domain made up of the Xixano, Lalamo, M'Sawize, and Muaquia complexes along with the Monapo and Mugeba klippen, grouped together here as the "Cabo Delgado Nappe Complex" (CDNC) and representing a "far-transported" upper nappe system, emplaced northwestward during the Pan-African orogeny (the nappes are lithologically very heterogeneous and are formed by granitic, tonalitic, gabbroic, amphibolitic gneisses and various paragneisses, metavolcanics, and mafic granulites); (4) the localized Neoproterozoic cover sequences of the Mecuburi and Alto Benfica groups (metaconglomerates, nodular, and biotite gneisses), overlying the Nampula Complex, and the Geci Group (limestones, mica schists, and metaconglomerates [e.g., Melezhik et al., 2006]) overlying the Unango Complex, and probably the Txitonga Group overlying the Ponta Messuli Complex; and (5) the Neoproterozoic Montepuez and Ocua complexes, interpreted as a Pan-African tectonic mélange including lithologies from megaunits 2 and 3, and with the Ocua Complex forming the core of the Lurio Belt.

[10] These megatectonic units were tectonically juxtaposed to form a regional-scale imbricate or nappe stack and their structural evolution during the Pan-African orogeny forms the main thrust of this paper.

\section{Methodology}

[11] The field surveys employed conventional mapping techniques, enhanced by Landsat TM, Shuttle DEM and geophysical images held within a GIS system. Fieldwork was conducted from numerous moving base camps by $4 \times 4$ vehicle and occasional helicopter access to particularly remote areas. In order to constrain the timing of critical deformational events, the geochronological data obtained during the course of the wider project were supplemented for this structural study with zircon and monazite dating on two samples from the Ocua Complex. The dates were obtained using standard CL imaging and analytical techniques at the Geological Survey of Norway as outlined by Norconsult Consortium [2007a].

[12] We utilize modern airborne geophysical data flown and processed in 2004 and 2005 by Fugro Airborne Systems Ltd. For a detailed description of our postprocessing treatment of the data, see Norconsult Consortium [2007b]. The data were acquired during five surveys known as block 4, block 5, block 6 east, block 6 west, and block B (red outlines in Figure 2). The flight line spacing in blocks
4, 5, 6 east, and 6 west is $300 \mathrm{~m}$. The line spacing in block B is $1000 \mathrm{~m}$. Flying directions are NW-SE for blocks 4 and 6 east, NE-SW for block 6 west, E-W for block 5 and N$\mathrm{S}$ for block B. The total flight line length is $415,000 \mathrm{~km}$, covering more than $50 \%$ of the surface area of geological mapping area "LOT 1 " and $\sim 40 \%$ of the "LOT $1 \mathrm{X}$ " mapping area.

[13] The new geophysical data include total magnetic field and full spectrum radiometric measurements. Our interpretation of the geophysical data is largely qualitative, based on visual examination of images of the data. The images include gray tone and color pseudorelief representations of total magnetic field anomaly data. We also relied heavily on ternary images of potassium-uranium-thorium concentrations from the radiometric data sets. Derivatives of the radioelement concentrations were subjected to unsupervised classification to reduce the data to 15 classes with characteristic radiometric signatures. The geographic areas corresponding to the radiometric classes are portrayed in images colored according to mean radioelement concentrations. The colored images based on radiometric classes are a useful simplification of the radioelement data and help locate boundaries between rock types.

[14] Any interpretation of airborne geophysical data should be anchored to a ground truth. Our ground truth is the assemblage of field observations from the LOT 1 and LOT 1X mapping program consisting of 6835 detailed geological observation sites within the geographic extents of the new airborne geophysical surveys. Ground truth observations were associated with the aforementioned 15 radiometric classes to further constrain the interpretation of the geophysical data.

[15] The new geophysical data sets cover only part of the mapped areas in Figure 2. We filled the gaps between surveys using total magnetic field measurements and total gamma count rates from airborne geophysical surveys from the late 1970s and early 1980s.

\section{Neoproterozoic Structural Development of NE Mozambique}

[16] The juvenile Mesoproterozoic high-grade gneiss complexes that make up the larger part of NE Mozambique (megatectonic unit 2, Figure 1b) evolved during the period circa 1.2 to $1.0 \mathrm{Ga}$ in response to a series of arc accretion events. The early deformation, metamorphism and related plutonism of these complexes is described elsewhere [e.g., Norconsult Consortium, 2007a; Macey et al., 2007] and are not discussed further, except where they are pertinent to the Pan-African deformational history. In the structural scheme of NE Mozambique adopted here, the presumed Mesoproterozoic deformational event is termed " $\mathrm{D}_{1}$ ", and subsequent Pan-African events are numbered " $\mathrm{D}_{2}$," " $\mathrm{D}_{3}$," etc. Localized subdivisions in time are designated $\mathrm{D}_{3 \mathrm{a}}, \mathrm{D}_{3 \mathrm{~b}}$, etc. Because the area under review is so vast $\left(\sim 260,000 \mathrm{~km}^{2}\right)$ and complex, most of the structural events are described by reference to certain well-studied areas of good outcrop or particularly illuminating areas of geophysical coverage, which exemplify the feature and/or structure under review. 


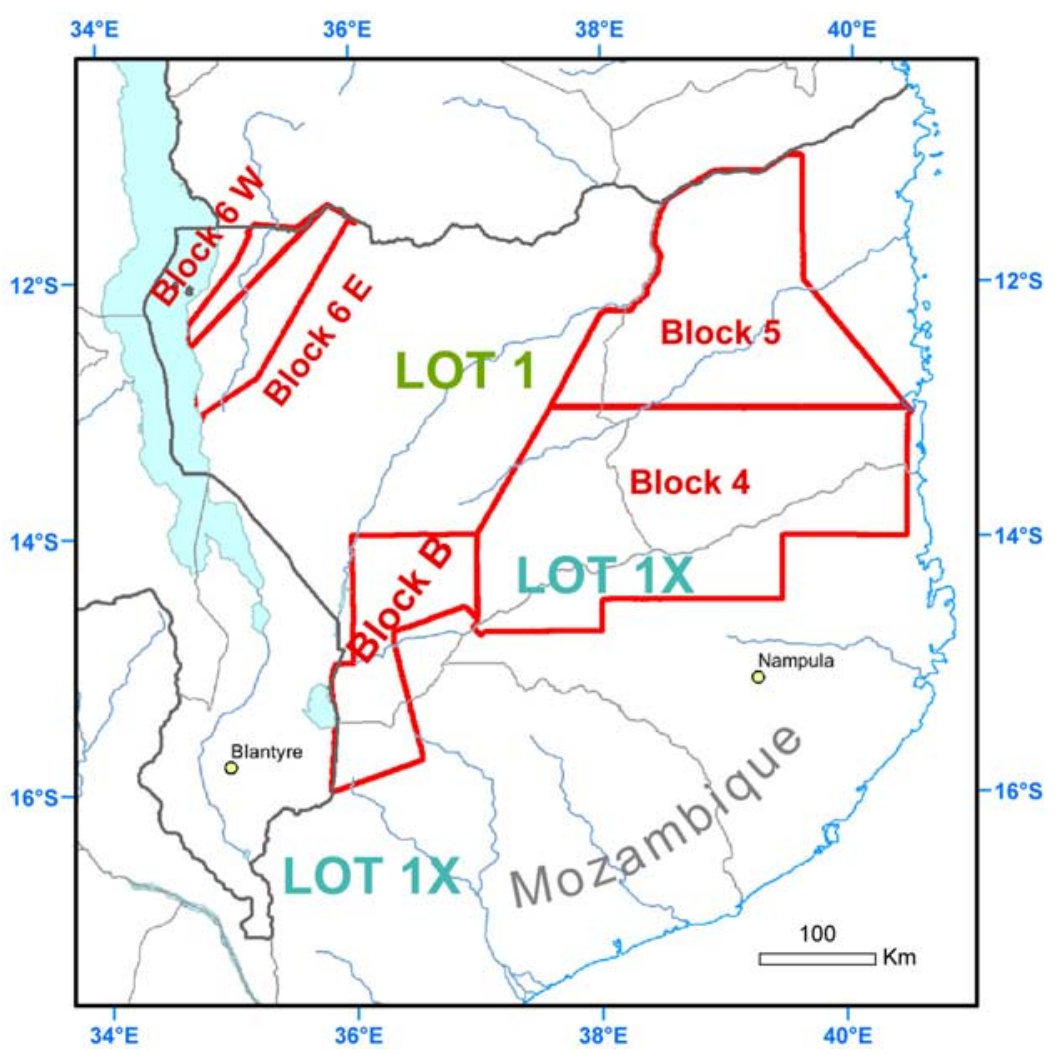

Figure 2. Location of geological mapping programs LOT 1 and LOT $1 \mathrm{X}$ and of airborne geophysical surveys block 4, block 5, block $6 \mathrm{E}$, block $6 \mathrm{~W}$, and block B.

The following sections systematically describe the structural features of each Pan-African deformational phase by reference to these critical studies areas and geophysical images.

\subsection{Early Pan-African NW-SE Crustal Compression and Nappe Imbrication}

[17] Our structural analysis starts with the characterization of a major, long-lived shortening phase that affected the entire area during the early stages of the Pan-African orogenic cycle and that created the overall, NW transported nappe stack geometry of NE Mozambique. Direct evidence for regional top-to-the-NW thrusting, although generally poor, is recorded along several of the main structural contacts separating the major imbricate packages (Figures $1 \mathrm{~b}$ and $1 \mathrm{c}$ ). We illustrate hereafter selected examples.

[18] Close to the shores of Lake Niassa, in the NW corner of the mapped area, the Neoproterozoic Txitonga Group overlies the Paleoproterozoic Ponta Messuli Complex along a generally SE dipping contact. There is evidence for intense shearing along the contact, with the Txitonga Group augen gneisses (which crop out south of the boundary) becoming increasingly foliated $\left(\mathrm{S}_{2}\right)$ northward, toward the contact itself. Although the actual contact does not crop out, numerous asymmetric, NW verging folds, associated with a pervasive SE plunging mineral stretching lineation, oriented at a high angle to their fold axes, suggest that the gneisses were thrust to the NW, obliquely over the Ponta Messuli Complex (Figure 3).

[19] Another important source of information on this phase is the contact between the Marrupa and Xixano complexes, which forms part of the basal contact between megaunits 2 and 3. It is generally poorly exposed in a largely inaccessible area along a length of several hundred kilometers. However, at several localities, strongly mylonitized rocks crop out and define a clear ductile tectonic contact, the presence and exact location of which is confirmed by the high-resolution geophysical survey. These high-resolution data disclose, with a remarkable degree of detail, that the easternmost $10 \mathrm{~km}$ of the Marrupa Complex have a strongly banded magnetic fabric (Figure 4a). As verified in the field, this fabric corresponds to a broad zone of mylonitization of the locally outcropping granite gneisses. Individual shear zones are from several meters to several hundreds of meters wide, demonstrating that this is, indeed, a major tectonic contact. Figures $4 \mathrm{~b}$ and $4 \mathrm{c}$ show field examples of this contact, where different kinematic indicators observed within the highly sheared and boudinaged granitoids consistently indicate a top-to-the-NW sense of shear. Such kinematics require that the Xixano Complex was structurally emplaced, SE to NW over the Marrupa Complex. Figures $4 \mathrm{~d}$ and $4 \mathrm{e}$ offer other examples of top-tothe-W and -NW kinematics along the same contact. Regional mapping also revealed small-scale top-to-the-SE 


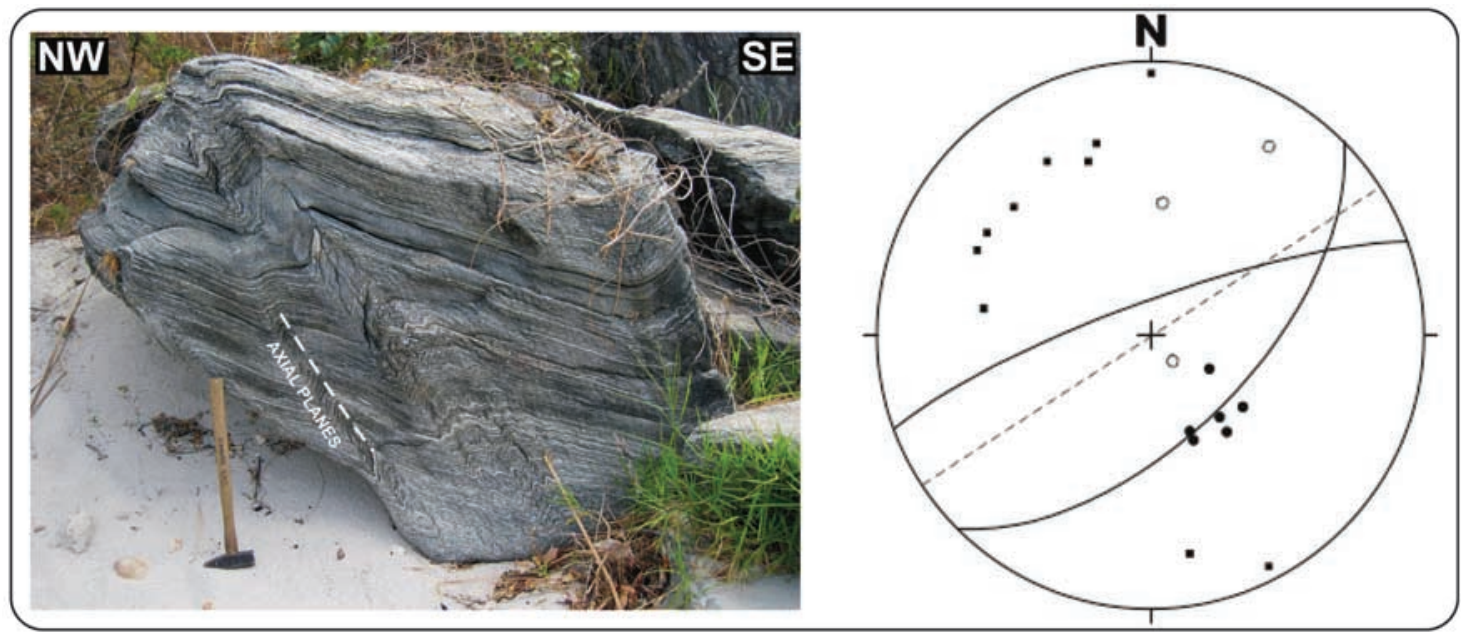

Figure 3. Detail of the western Txitonga contact with the underlying Paleoproterozoic Ponta Messuli Complex (UTM 36S, 690072, 8655901). Although the actual thrust contact is not exposed, consistently NW vergent asymmetric folds intensify toward the contact. The orientation of these folds is shown by the stereonet to the right (equal-area projection, lower hemisphere), where squares are poles to foliation, solid circles are mineral stretching lineations, great circles plot the average fold limbs orientation, and open circles are fold axes.

thrusts scattered throughout the region. These are mostly located within the individual nappes and are interpreted as the expression of local back thrusting, related to the same period of crustal shortening, and represent subsidiary, secondorder structures, with an overall opposite vergence to the regional nappe transport direction [Norconsult Consortium, 2007a]. More detailed work would be necessary to fully characterize the kinematic significance of these structures within the regional framework of NE Mozambique, although similar SE directed back thrusts are also reported by Muhongo [1994] in the similar structural setting of Neoproterozoic collision tectonics and regional NW directed nappe transport in the Uluguru Mountains of Tanzania.

[20] As noted, the current tectonic and crustal architecture of NE Mozambique is largely shaped by the extensive nappe stack, which formed in response to this shortening episode, and the tectonostratigraphic column of Figure $1 \mathrm{~b}$ reflects the resulting imbricate geometry. We thus envisage an early Pan-African tectonic framework of moderately to shallowly approximately SE dipping nappe imbricates, the "Cabo Delgado Nappe Complex" (CDNC) and we assign the whole of megaunit 3 to the CDNC. Evidence supporting the nappe model has also provided robust constraints on its geometric characteristics. For example, Pinna and Marteau [1987] documented a relatively small body of granulitic gneisses in the Nipepe region (Figure 5a) and had assigned it to their "Lurio Super Complex" (an approximate correlative of the newly established Ocua Complex megaunit 5). Here, two bodies of granulite are enveloped by fine- to medium-grained, high-grade migmatitic garnetiferous, quartzo-feldspathic paragneisses of the Marrupa Complex. Both granulite bodies are lithologically and structurally discordant with their substratum. Geophysical images of the two bodies are shown in Figure 5a, where it can be seen that the internal structural grain of the larger, eastern unit strikes north-south, at a high angle to the ENE-WSW trend of the underlying rocks of the Marrupa Complex. On the basis of the geophysics and field observations, we interpret these two units as forming an erosional klippen, here called the "Nipepe klippen" (Figure 5a). Furthermore, the geophysical data, together with observed lithological similarities, allow the correlation of the Nipepe rocks with the Xixano Complex nappe farther to the NE (Figure 5a). We propose therefore that the Nipepe klippen formed part of the once much larger Xixano Complex nappe, and consequently can be used to pinpoint the minimum western lateral extent of the entire Xixano nappe of the CDNC. The klippen are preserved by virtue of their location within the core of a later $\mathrm{F}_{3}$ synform (see below).

[21] Further evidence in favor of a regional-scale nappe imbricate model can be gained by an analysis of the radiometric classes of the study area. Radiometric classes group lithologies of comparable $\mathrm{U}$, Th and $\mathrm{K}$ signature and can be used to map specific lithotectonic units (Figure 5b). Figure $5 \mathrm{~b}$ provides details of the possible minimum lateral extent of some of the Pan-African nappes of the CDNC, which reconnaissance fieldwork alone could not have revealed. Confirming the interpretation of the Figure 5a, Figure 5b shows radiometric classes for a large area of Figure 1a. Identical radiometric classes (black and dark blue colors) at sites A (Nipepe klippen) and B (SW folded termination of the Xixano Complex) strengthen their correlation. On the basis of the results of the radiometric class analysis, it can furthermore be suggested that the Xixano Complex extended even farther west than the Nipepe klippen, at least to the sites marked C. Moreover, site D indicates the possible minimum southern extent of the 


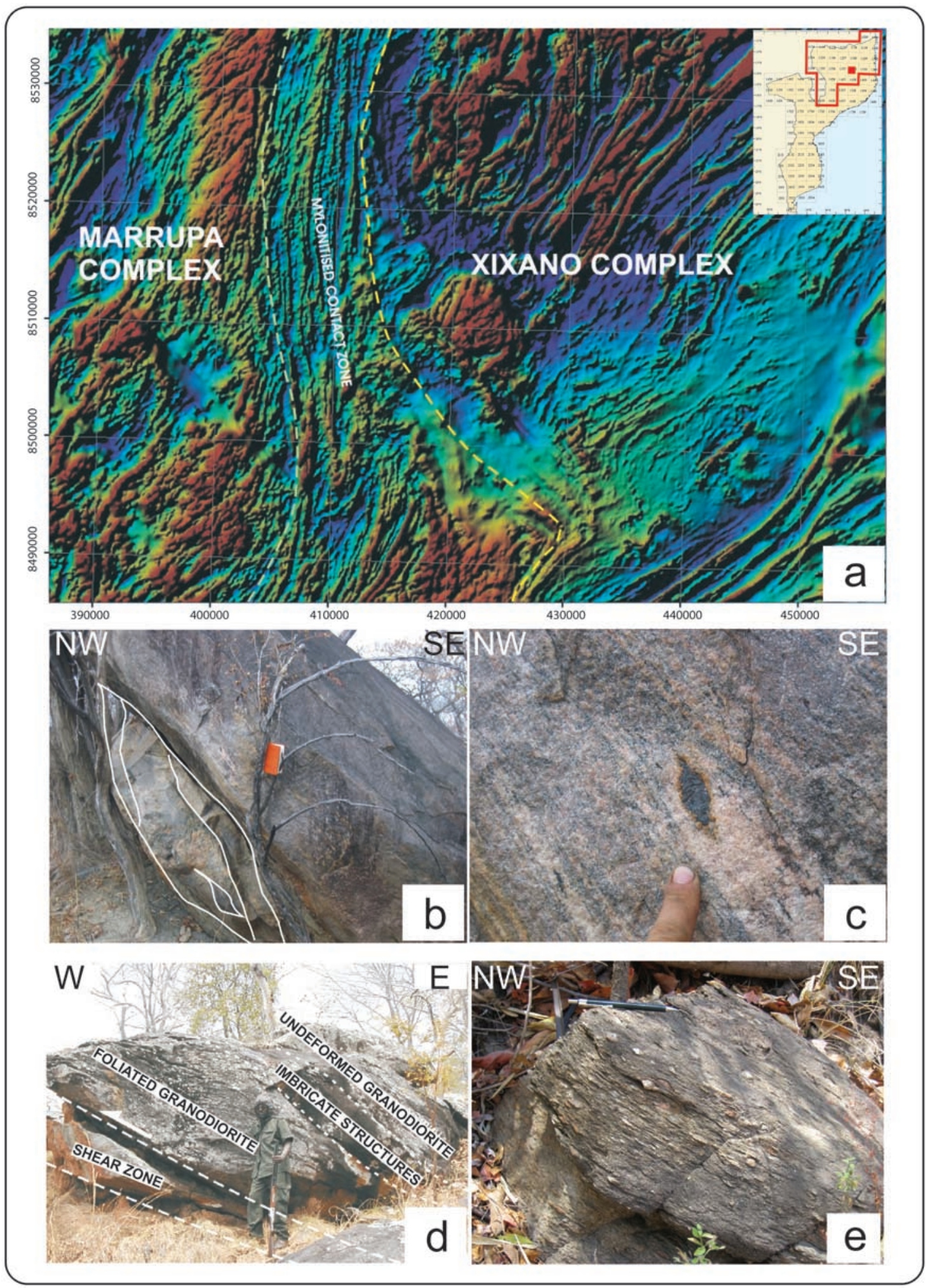

Figure 4 
complex. Site D is located significantly to the south of the Lurio Belt, within the Nampula Complex. In addition, immediately to the north of site D there are elements of the Xixano Complex that are structurally reworked in the Lurio Belt. This observation gave much support to the interpretation of the Ocua Complex as a tectonic mélange in the core of the Lurio Belt and incorporating slivers of the neighboring tectonostratigraphic complexes. Sites E mark two chosen localities within the Lurio Belt characterized by the occurrence of Ocua- and Marrupa-type rocks. Site F farther to the north has the same radiometric characteristics, supporting the model whereby the Ocua Complex (and part of the structural fabric of the Lurio Belt) is folded around WSW plunging upright folds, as indicated by the white line of Figure $5 b$ (see below for more details).

[22] In terms of the timing of nappe stacking, we still lack direct geochronological data, though there are indirect constraints. Nappe stacking is younger than the metamorphic and magmatic events specific to the transported nappes, i.e., events not recorded in the underlying Mesoproterozoic domain (Unango, Marrupa and Nampula complexes). On the other hand, the youngest granite situated near the base of the Xixano nappe and affected by deformation related to nappe stacking was dated at $596 \pm 11 \mathrm{Ma}$ during our study [Norconsult Consortium, 2007a], thereby providing a maximum age for the thrusting.

[23] A related structure, the Mugeba Complex klippen, which lies well south of the Lurio Belt partly in the study area (Figure 1c), has a tectonic basal contact [e.g., Sacchi et al., 1984, 2000] and underwent granulite facies metamorphism at $615 \pm 7$ Ma [Kröner et al., 1997]. This Neoproterozoic date confirms the allochthonous origin of the Complex, as it rests tectonically upon the Nampula Complex, which underwent pervasive, younger, Pan-African metamorphism (circa $550 \mathrm{Ma}$ and younger [Norconsult Consortium, 2007a]). The age of emplacement of the Mugeba klippen is thus bracketed between $615 \pm 7$ and $550 \mathrm{Ma}$. The $615 \mathrm{Ma}$ date is the youngest metamorphic age available so far from the whole nappe system, whereas $550 \mathrm{Ma}$ is the metamosphism age in the underlying Marrupa Complex [Norconsult Consortium, 2007a]. We thus use lithological and structural similarities to support a model whereby the Mugeba klippen (and possibly also the structural correlative Monapo klippen farther east) is part of the CDNC that outcrops much more extensively to the north of the Lurio Belt.

\subsection{Crustal-Scale NE-SW to ENE-WSW Trending Folds}

[24] The NW-SE oriented shortening event that led to the formation of the CDNC evolved continuously with time into a more diffuse deformation episode that eventually shortened the whole imbricate system via a set of NE-SW to ENE-WSW trending crustal-scale folds. The axial traces of the most significant of these F3 folds are shown in Figure 6a. A first fundamental observation is that early, $\mathrm{D}_{2}$ structures associated with nappe imbrication are folded by these folds. For example the mylonitic top-to-the-NW contact separating the Xixano and Marrupa complexes (Figure 6b) is folded by these structures, clearly demonstrating that the folding is post nappe stacking. This suggests that the progressive evolution of the shortening accommodation mechanisms evolved from discrete thrusts at the base of individual imbricated crustal slices to continuous, diffuse folding, as typical for many fold and thrust belts. These folds are very common in the entire area, although their geometry changes significantly from open to tight and even isoclinal depending upon the lithotectonic unit within which they occur. They also appear to decrease in wavelength and become tighter on a regional scale toward the Lurio Belt suggesting that their formation is intimately related to the evolution of the Lurio Belt.

[25] Given that our study shows that the Lurio Belt forms an integral part of this folding framework, and that the mylonitic fabric of the belt is axial planar to the F3 folds, we will now discuss the Lurio Belt in some detail, before addressing the significance of this regional-scale folding phase.

\subsection{Lurio Belt: Expression of Continued NW-SE Pan- African Regional Compression}

[26] The Lurio Belt forms the most prominent linear tectonic feature in NE Mozambique (Figure 7). It is defined on a regional scale as a generally ENE-WSW striking shear zone, except in its easternmost sector, where the belt swings to an east-west orientation. Farther to the west, toward the Malawi border, the structure becomes much more diffuse and ill-defined. The regional geodynamic significance and relative importance of the belt has been discussed in several studies and is still being actively debated [e.g., Jourde and Vialette, 1980; Pinna et al., 1993; Kröner et al., 1997; Jamal, 2005], with some workers suggesting that it represents a major collisional suture zone between north and south Gondwana [e.g., Grantham et al., 2003, 2008].

Figure 4. Multiscalar evidence for early Pan-African NW directed thrusting. (a) The $\sim 10 \mathrm{~km}$ wide tectonized contact of the Marrupa Complex with the overlying Xixano Complex as seen from intense linear tectonic fabric revealed by highresolution total magnetic field anomaly measurements (block 4; pseudorelief effect with light source in NW; UTM 37S coordinates). Field evidence of top-to-the-NW thrusting along the same contact (Figures 4b and 4c). (b) Top-to-the-NW megasigma clast with internal imbricates. (c) Centimetric top-to-the-NW sigma clast (UTM 37S 445717, 8653562). (d) Ductile shear zone deforming a granodioritic intrusion at UTM 37S 182787, 8637120. The main shear zone, which is a minimum of $50 \mathrm{~cm}$ wide, has $2 \mathrm{~m}$ of well-foliated granodioritic intrusion in its hanging wall. Imbricate structures give a dip-slip reverse component of shear (top-to-the-W). (e) Intranappe ductile thrust within the Xixano Complex, producing strongly sheared augen gneisses (UTM 37S, 438189, 8638844). Asymmetric clasts in the augen gneiss confirm top-to-theNW transport. 


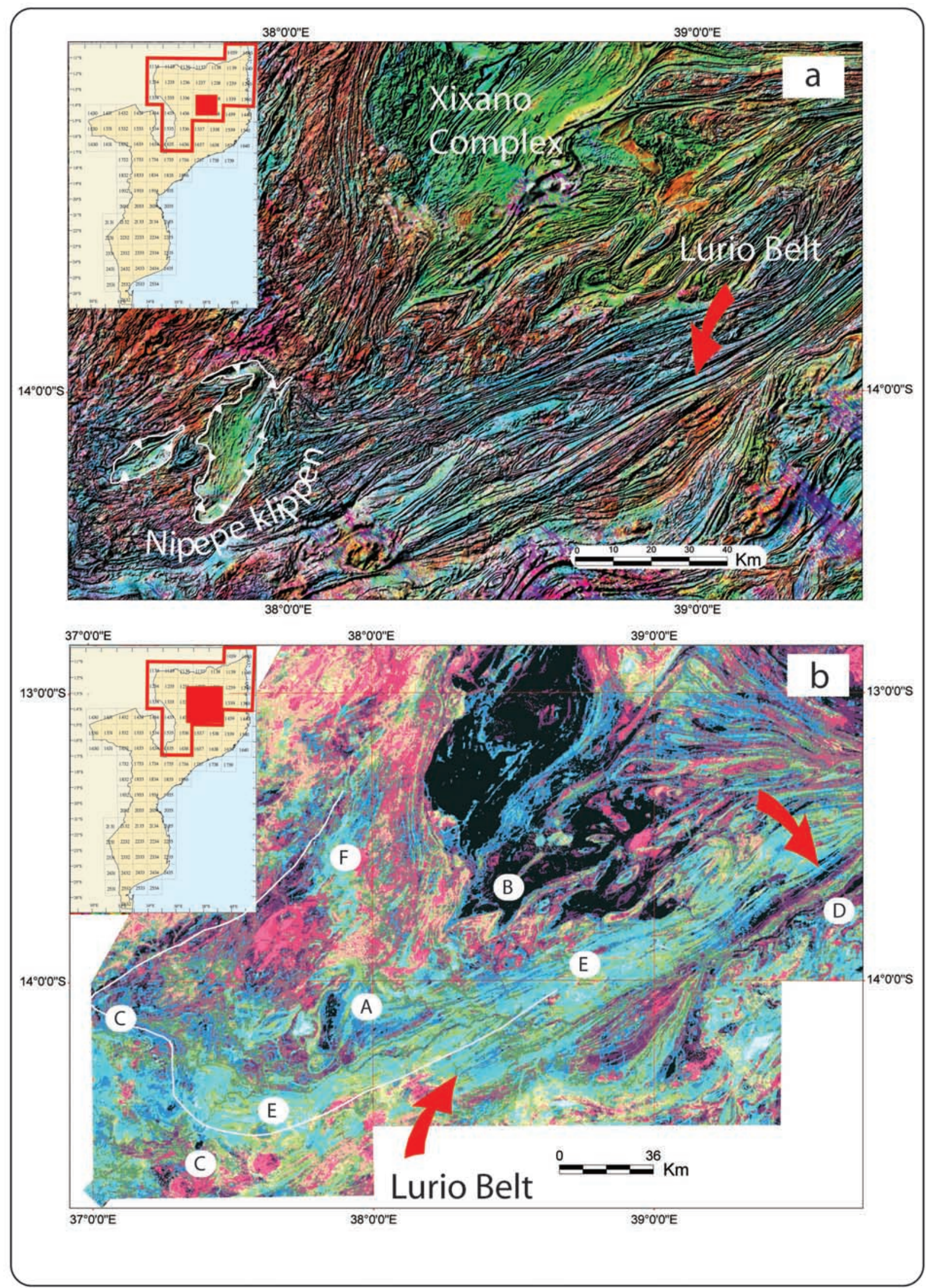

Figure 5 
[27] While all generally agree that within the belt there was significant deformation and metamorphism of approximately 1100 Ma old rocks during the Pan-African orogeny between 650 and $460 \mathrm{Ma}$, the detailed field relationships, geometry and kinematics of the belt have so far been poorly constrained, partly due to poor outcrop conditions. The bulk sense of movement has thus been typically described as sinistral (although overall dextral kinematics have also been suggested [e.g., Jacobs and Thomas, 2004]), or transpressional with both strike-slip and downdip components recognized. In most studies, however, kinematics were often constrained by the requirements of geochronological and petrological information and large-scale tectonic reconstructions, rather than detailed field structural studies. Most regional models thus envisage the Lurio Belt primarily as accommodating top-to-the-SE directed thrusting, inferred to be the mechanism responsible for the exhumation of PanAfrican granulites in the core of the belt and their juxtaposition against the Nampula Complex to the south. Only Jamal [2005] carried out a modern field structural study of the belt (especially in its eastern sector). He proposes a fourphase deformational scheme $\left(D_{1}-D_{4}\right)$, where $D_{2}$ appears to be the most intense phase of deformation, characterized by $\mathrm{NE}-\mathrm{SW}$ isoclinal folds with $\mathrm{S}_{2}$ axial planar foliation. In that study $\mathrm{D}_{2}$ is also associated with SE directed thrusts, although no convincing evidence is presented. NE-SW open to tight subvertical folds and development of an $\mathrm{S}_{3}$ axial planar foliation mark $\mathrm{D}_{3}$, which is described as resulting from a transpressive regime. The effects of $\mathrm{D}_{3}$ are described as being very penetrative, so that $S_{2}$ and $S_{3}$ are virtually indistinguishable due to the intense transposition and flattening of $\mathrm{D}_{2}$ structures. Jamal [2005] characterizes $\mathrm{D}_{4}$ with NW-SE extensional brittle-ductile dextral shear zones, filled with pegmatites and aplites.

[28] We found this scheme not entirely applicable to our own observations and in the next sections we present therefore an independent analysis of the deformational features mapped within the Lurio Belt. Our field investigation shows that the Lurio Belt is actually characterized by remarkably different structural features in the east and west, warranting a separate discussion of the two domains (Figure 7). We recognized what are interpreted to be the oldest structures within the belt as being preserved exclusively in its western and central sector and our analysis will therefore begin from these subareas, before considering the eastern sector (Figure 7). Farther to the SW, the Lurio Belt as such cannot be recognized as a singular tectonic entity, though a series of poorly exposed anastomosing shear zones forms the boundary between the Nampula and Unango complexes all the way to the Malawi border (Figure 1c).

\subsubsection{Western Lurio Belt: A Complex History of Shortening and Folding}

[29] The western Lurio Belt is generally characterized by a pervasive planar fabric striking ENE-WSW and dipping $30-45^{\circ} \mathrm{NW}$ (Figure 7). The dominant fabric is defined at the outcrop scale by a penetrative gneissic foliation, locally protomylonitic to mylonitic, and by strong transposition and lateral attenuation of the granulites of the Ocua Complex [Norconsult Consortium, 2007a]. The foliation in this segment of the belt is a composite $\mathrm{S}_{2} / \mathrm{S}_{3 \mathrm{a}}$ transposed planar fabric, derived from the isoclinal folding and transposition/ attenuation of the $\mathrm{S}_{2}$ foliation around ENE-WSW trending isoclinals folds $\left(\mathrm{F}_{3 \mathrm{a}}\right.$ folds, see below). The $\mathrm{S}_{2}$ fabric is defined by a pervasive metamorphic foliation outlined by alternating felsic segregations and mafic layers, and is itself axial planar to an earlier generation of tight to isoclinal folds that refold an earlier $S_{1}$ fabric, which is only very sporadically preserved in low-strain areas. Stretching lineations and crenulation axes associated with the $\mathrm{S}_{2} / \mathrm{S}_{3 \mathrm{a}}$ composite fabric are defined by hornblende, biotite or coarse quartz crystals. They display a scattered spatial distribution but can nonetheless be grouped into two coarse main clusters (stereonets in Figures 7 and 8):

[30] 1. A first, rather distinct but scattered group of lineation measurements has a gentle to moderate plunge to the NW. This plunge direction is peculiar of the Lurio Belt in this whole subarea and most of the NW plunging lineations represent crenulation axes of an early fold generation $\left(\mathrm{F}_{2}\right)$, together with NW plunging stretching lineations. Given the high degree of $\mathrm{S}_{2}$ transposition into $\mathrm{S}_{3 \mathrm{a}}$ (which locally totally overprints $S_{2}$ and represents the regional mylonitic fabric of the belt), evidence of $\mathrm{D}_{2}$ is not preserved extensively and only a few outcrops could be documented (red crosses in the stereonet of Figure 8 represent definite $\mathrm{F}_{2}$ fold axes). As an example, Figure 8a shows an outcrop containing a mesoscopic, NW plunging inclined $F_{2}$ fold. The $S_{2}$ foliation is axial planar to the fold, which refolds an earlier $\mathrm{S}_{1}$ fabric. Figure $8 \mathrm{~b}$ shows another example of a NW plunging fold, but with isoclinal geometry and partially transposed limbs. Figure $8 \mathrm{c}$ shows an $\mathrm{S}_{2}$ cleavage dipping $35^{\circ} \mathrm{NW}$ that is axial planar to NW plunging folds. The origin of these folds, as well as of the earlier $\mathrm{S}_{1}$ fabric, their associated cleavages, and the explanation of how their different style and orientation fit into regional structural models are not clear. It is important to stress, however, that $\mathrm{D}_{2}$ structures were found only in the

Figure 5. (a) Ternary radioelement image with pseudorelief effect based on total magnetic field anomaly values (blocks 4 and 5; virtual light source in the NW). White lines outline the "Nipepe klippen," made up of two bodies whose identification has been possible only due to the integration of field observations and the interpretation of the new geophysics. Note the affinities between the radiometric signature and the structural grain orientation of the Nipepe klippen and the Xixano Complex to the NE. (b) Ternary image of radiometric classes derived from the new geophysical data (blocks 4 and 5; red, potassium; green, thorium; blue, uranium). The radiometric signal can be used to make inferences on the possible minimum lateral extent of the Pan-African CDNC nappes. Letters refer to sites of specific interest discussed in the text. Red arrows point to the NE-SW trending Lurio Belt. 


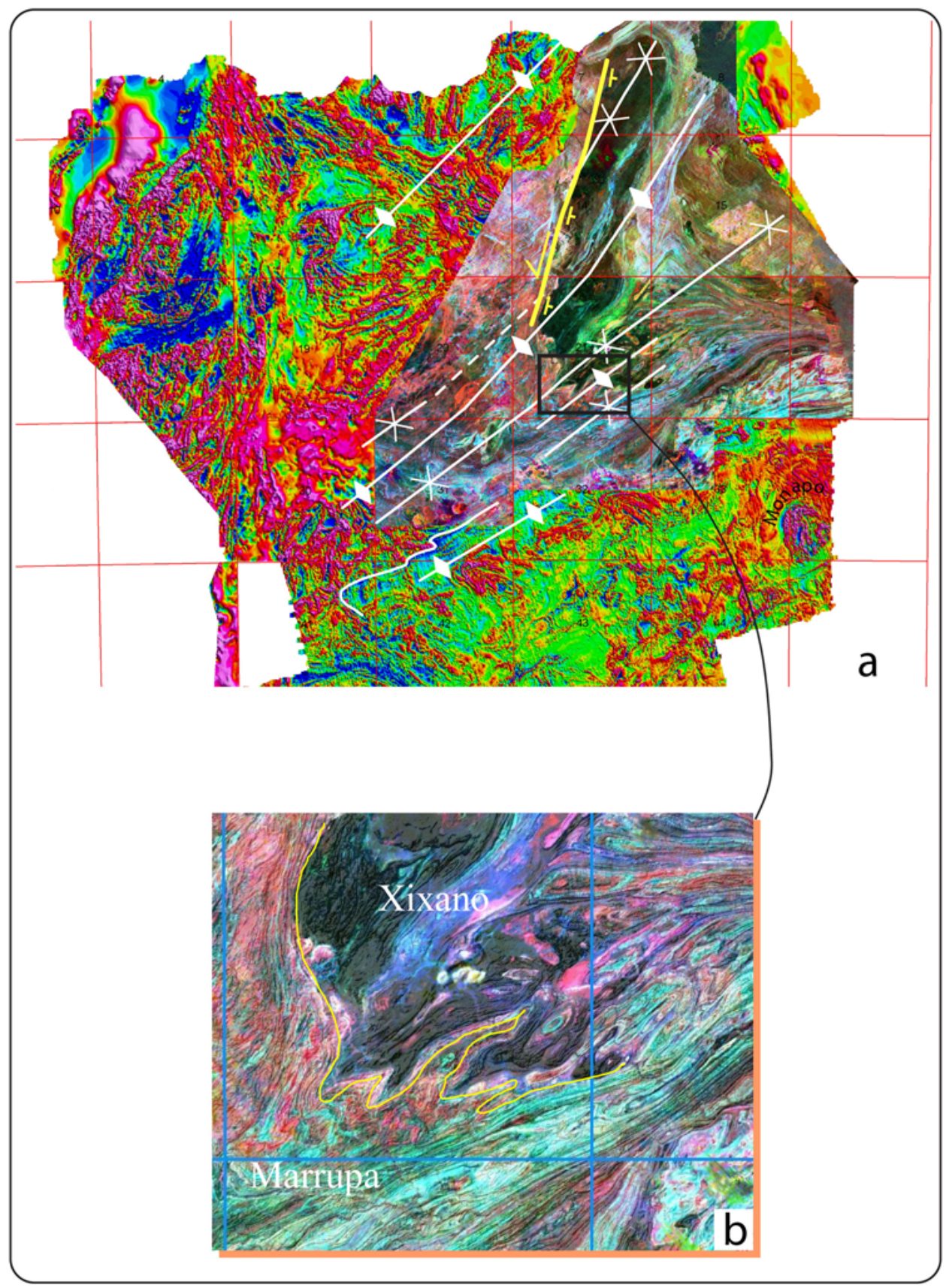

Figure 6. (a) Structural interpretation of the geophysical data for northern Mozambique. Survey blocks 4 and 5 show ternary image of radiometric data; all other areas show colored and shaded total field anomaly data. Traces of the main regional-scale $\mathrm{F}_{3 \mathrm{~b}}$ folds recognized are shown. (b) Enlargement of the Marrupa-Xixano Complex tectonic contact that is clearly folded by $\mathrm{F}_{3 \mathrm{~b}} \mathrm{NE}-\mathrm{SW}$ trending folds. Ternary radioelement image.

westernmost part of the Lurio Belt and seem to be missing farther east, probably due to the strong deformation overprint that affected the eastern Lurio Belt during the latest stages of NW-SE compression (see below). Moreover, no clear $\mathrm{D}_{2}$ kinematic indicators were found and therefore no reliable evidence of significant across- or along-strike shear associated with the early development of the Lurio Belt could be documented.

[31] 2. The second linear fabric cluster (Figure 7, 8, and 9; Figure 9 shows both linear fabrics preserved within the same mylonitic rock of the Ocua Complex) is formed by generally west to WSW plunging fold axes. These folds are 


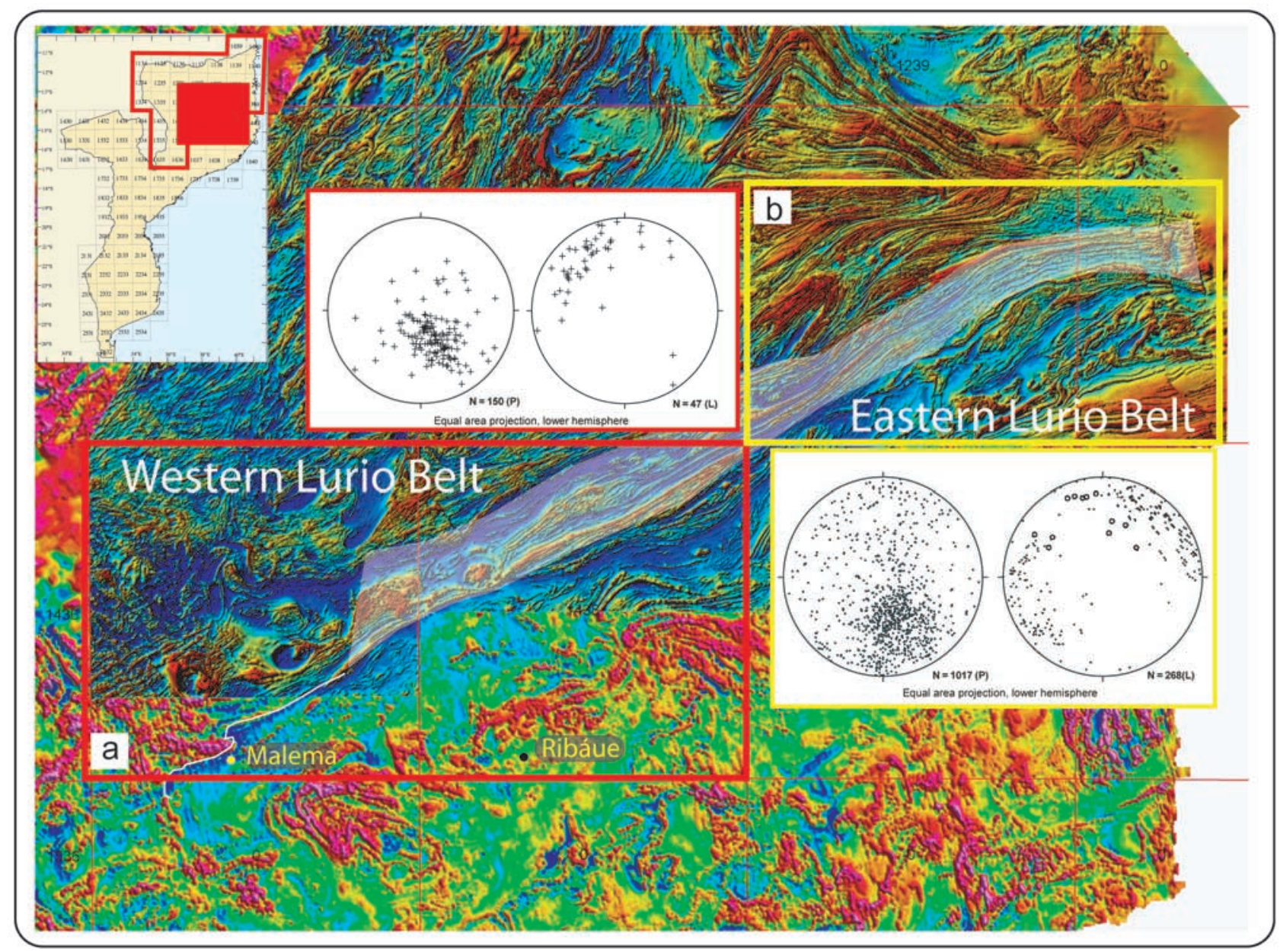

Figure 7. Total magnetic field anomaly data over the Lurio Belt. Color presentation with pseudorelief effect. High-resolution data over survey blocks 4 and 5 (including Lurio Belt); vintage data elsewhere. Note the strong linear structural grain of the Lurio Belt and how this fades progressively away in the westernmost part of the structure, due to its infolding. (a) Stereonet data for the western Lurio Belt, with poles to mylonitic foliation (crosses in the left-hand side stereonet) and linear elements (crosses in the right-hand side stereonet, plotting crenulation axes and stretching lineations). (b) Stereonet data (equalarea, lower hemisphere projection) for the eastern part of the Lurio Belt showing poles to (left) foliation and (right) mineral stretching lineation. The foliation displays a much wider spread in orientation than that in the western Lurio Belt. This is probably a result of the more intense folding and later overprint discussed in the text, which also caused the $\mathrm{E}-\mathrm{W}$ orientation of the easternmost part of the belt. Unlike the western Lurio Belt, the mineral stretching lineations (solid dots) are shallowly plunging on a WSW ENE trend within the foliation planes and represent a strike-slip overprint not seen in the western Lurio Belt. Open circles plot $\mathrm{N}-\mathrm{NW}$ plunging stretching lineations kinematically associated with the subsequent late Pan-African extensional phase.

assigned in our study to a post- $\mathrm{F}_{2}$ folding episode, referred to as $\mathrm{F}_{3}$ (with early and late subevents designated $\mathrm{F}_{3 \mathrm{a}}$ and $\left.\mathrm{F}_{3 \mathrm{~b}}\right)$. The $\mathrm{F}_{3 \mathrm{a}}$ folds are very tight to isoclinal and generally subhorizontal (Figures 8d-8f). Only a few exposures could be documented within the belt due to the scarcity of outcrops and severe later fabric transposition, although these folds are readily apparent from the aeromagnetic data and have also been shown previously at a 1:1,000,000 scale by Pinna and Marteau [1987]. Locally within the Lurio Belt these folds are significantly flattened and disrupted along their limbs leading to significant fabric transposition. The example in Figure 8d shows asymmetric $\mathrm{F}_{3 \mathrm{a}}$ tight folds with subhorizontal axial planes. Their recumbent attitude is due to subsequent folding around slightly younger coaxial open folds, $\mathrm{F}_{3 \mathrm{~b}}$ folds. $\mathrm{F}_{3 \mathrm{a}}$ fold axes plunge gently $\mathrm{W}-\mathrm{WSW}$ and form coarse intersection lineations on the foliation planes (Figure 8e). Figure $8 \mathrm{f}$ shows an $\mathrm{F}_{3 \mathrm{a}}$ isoclinal fold deforming and transposing Lurio $\mathrm{S}_{2}$ foliation planes. It is clear that most of these ENE-WSW trending folds have NW to NNW dipping axial planes that correspond in orientation 

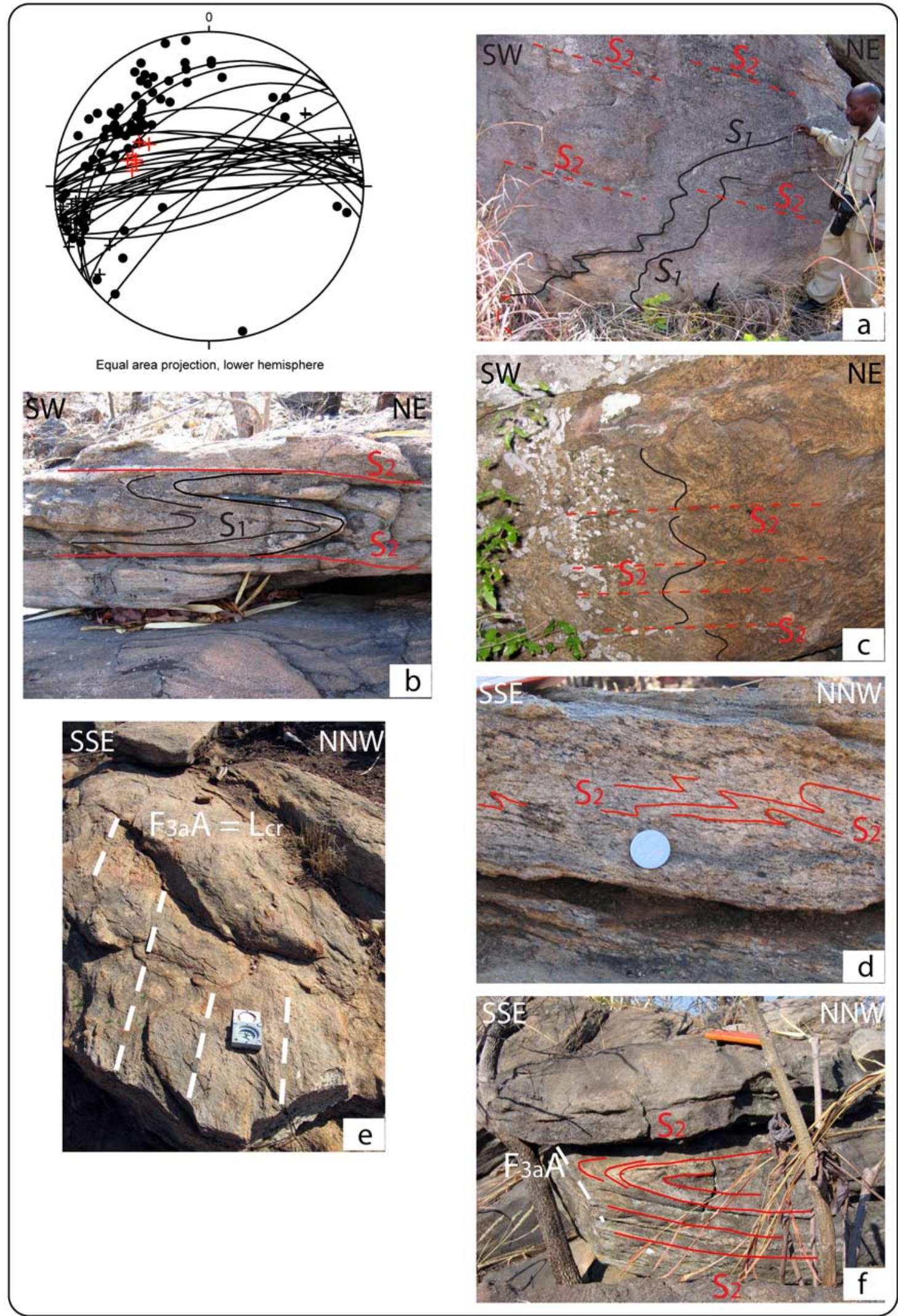

Figure 8 


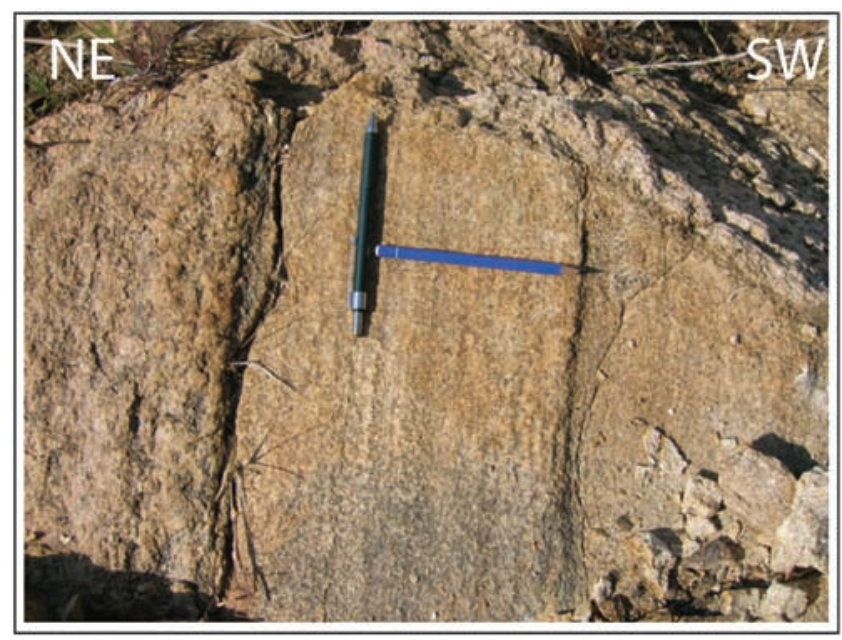

Figure 9. NW plunging stretching lineation/crenulation axis (green pencil) and WSW plunging crenulation axis (blue crayon) preserved on a strongly sheared leucogneiss within the Lurio Belt.

to the overall planar attitude of the Lurio Belt foliation (Figure 7), thus confirming the composite axial planar origin of the belt regional foliation.

[32] In contrast to the scarcity of mesoscale $\mathrm{F}_{3 \mathrm{a}}$ folds, $\mathrm{F}_{3 \mathrm{~b}}$ folds are the most common structural feature in the whole area and outcrop at all scales. These are the folds mentioned in section 4.2 and represent the result of continuous shortening by folding of the $\mathrm{S}_{2} / \mathrm{S}_{3 \mathrm{a}}$ transposed fabric about identically oriented axes. They trend consistently ENEWSW (stereonet in Figure 10) and occur both as isolated folds as well as continuous fold trains (see the many examples of Figure 10). $\mathrm{F}_{3 \mathrm{~b}}$ folding took place under amphibolite facies conditions as suggested by abundant quartz-plagioclase leucosomes that inject polyphase migmatitic rocks along the $\mathrm{F}_{3 \mathrm{~b}}$ axial plane directions (e.g., Figures 10b, 10f, and 10h) and by the assemblage hornblende-garnet that wraps around primary granulite assemblages within the Ocua Complex granulites in structural sites geometrically linked to this folding phase. $\mathrm{S}_{3 \mathrm{~b}}$ axial plane cleavage, defined by quartz-plagioclase leucosomes, can be very pervasive at the outcrop scale within migmatites with high-melt proportions (Figures 10b, 10f, and 10h).

[33] $\mathrm{F}_{3 \mathrm{a}}$ and $\mathrm{F}_{3 \mathrm{~b}}$ folds are coaxial and are interpreted as having been formed during the same progressive shortening event. They are distinguished by their differing geometries.
$\mathrm{F}_{3 \mathrm{a}}$ folds are tight to isoclinal and are generally typical of the Lurio Belt. Within the belt, probably due to the presence of an older, inherited mechanical weakness zone, which is presumably linked to $\mathrm{D}_{2}$ and/or older events, they locally accommodated large amounts of strain. In contrast, the $\mathrm{F}_{3 \mathrm{~b}}$ folds, which are found throughout NE Mozambique, are more open and there is evidence suggesting that they postdate $\mathrm{F}_{3 \mathrm{a}}$. As mentioned above, the entire Lurio Belt structure, whose internal mylonitic fabric is axial planar to $\mathrm{F}_{3 \mathrm{a}}$ folds, is itself folded around the $\mathrm{F}_{3 \mathrm{~b}}$ axes. This conclusion is supported by the interpretation of geophysical patterns (Figure 11a) and by the mapping of outcrops of the Ocua Complex gneiss. First, south of Malema, foliations flatten out around a fold axis plunging gently $\mathrm{W}-\mathrm{WSW}$, such that dips to the SE are locally recorded (Figure 11b). Second, the southernmost boundary of the Lurio Belt is marked by a strongly sheared, quartz-ribbon feldspathic leucogneiss, which is geophysically characterized by a strong magnetic low and dates at $538 \mathrm{Ma}$ (sample 26878/ RT515 of Norconsult Consortium [2007a]). Figure 11a shows that this unit is folded by relatively open $\mathrm{F}_{3 \mathrm{~b}}$ axes (white dashed lines), which, immediately south (within the Nampula Complex), refold an earlier, $\mathrm{F}_{3 \mathrm{a}}$ isoclinal fold (shown by the dashed black axial trace on Figure 11a).

[34] As already noted, to the west of this fold closure, the structural grain of the Lurio Belt becomes very weak and difficult to define in the field. The geophysical signature also becomes less pronounced (see, for example, Figures 6 and 7). We interpret this to be due to folding that, in the hinge zone of the large-scale $F_{3 b}$ folds, flattens out the fabric and weakens the map view of the strong linear trend present farther east. This is in agreement with the observation that the strong ENE-WSW planar fabric that characterizes the Lurio Belt in the eastern part of this sub area is gradually lost to the west, where there is a progressive largescale bending of the foliation to a NW strike. The relative scatter of Lurio Belt poles to foliation around the strong southeast plunging main cluster shown in Figure 7 reflects the increase of structural complexity in this area. Lurio fabrics, and together with them the Ocua Complex lithologies, are in fact folded around and transposed by generally $\mathrm{NE}-\mathrm{SW}$ trending $\mathrm{F}_{3 \mathrm{~b}}$ folds and in the hinge area they attain shallower dips and mostly northwest-southeast strikes (see also the white outline of Figure 5b).

[35] Other evidence of this compression and shortening episode is not restricted to the Lurio Belt, but is found consistently throughout the region, not only in the form of crustal-scale folds, but also as localized intense structural

Figure 8. Structures from the western Lurio Belt. The stereonet plots $\mathrm{F}_{3}$ axial planes (great circles) and lineations (solid dots). In the NW plunging lineation cluster, given the high degree of fabric transposition, there are difficulties in separating mineral and stretching lineations from crenulation axes and thus intersection lineations. Many of the NW plunging lineations are thus likely to be $F_{2}$ crenulation axes. Red crosses represent positively identified $F_{2}$ fold axes. The W-WSW plunging linear elements (black crosses) are $\mathrm{F}_{3}\left(\mathrm{~F}_{3 \mathrm{a}}\right.$ and $\left.\mathrm{F}_{3 \mathrm{~b}}\right)$ fold axes. (a) Moderately NW plunging $\mathrm{F}_{2}$ fold, which refolds an earlier $S_{1}$ fabric. (b) NW plunging isoclinal F2 fold. Note the isoclinal geometry and the transposed limbs. (c) NW dipping $S_{2}$ cleavage, axial planar to $F_{2}$ folds plunging moderately northwest. (d) Train of asymmetric $\mathrm{F}_{3 \mathrm{a}}$ fold rotated to a recumbent attitude by later $\mathrm{F}_{3 \mathrm{~b}}$ folding. (e) White dashed lines highlight $\mathrm{F}_{3 \mathrm{a}}$ crenulation axes $\left(\mathrm{F}_{3 \mathrm{a}} \mathrm{A}\right)$ of the folds shown in Figure 8d. $\mathrm{L}_{\mathrm{cr}}$ stands for crenulation lineation. (f) $\mathrm{F}_{3 \mathrm{a}}$ isoclinal fold transposing $\mathrm{S}_{2}$ fabric. The fold is recumbent due to later $\mathrm{F}_{3 \mathrm{~b}}$ folding. 


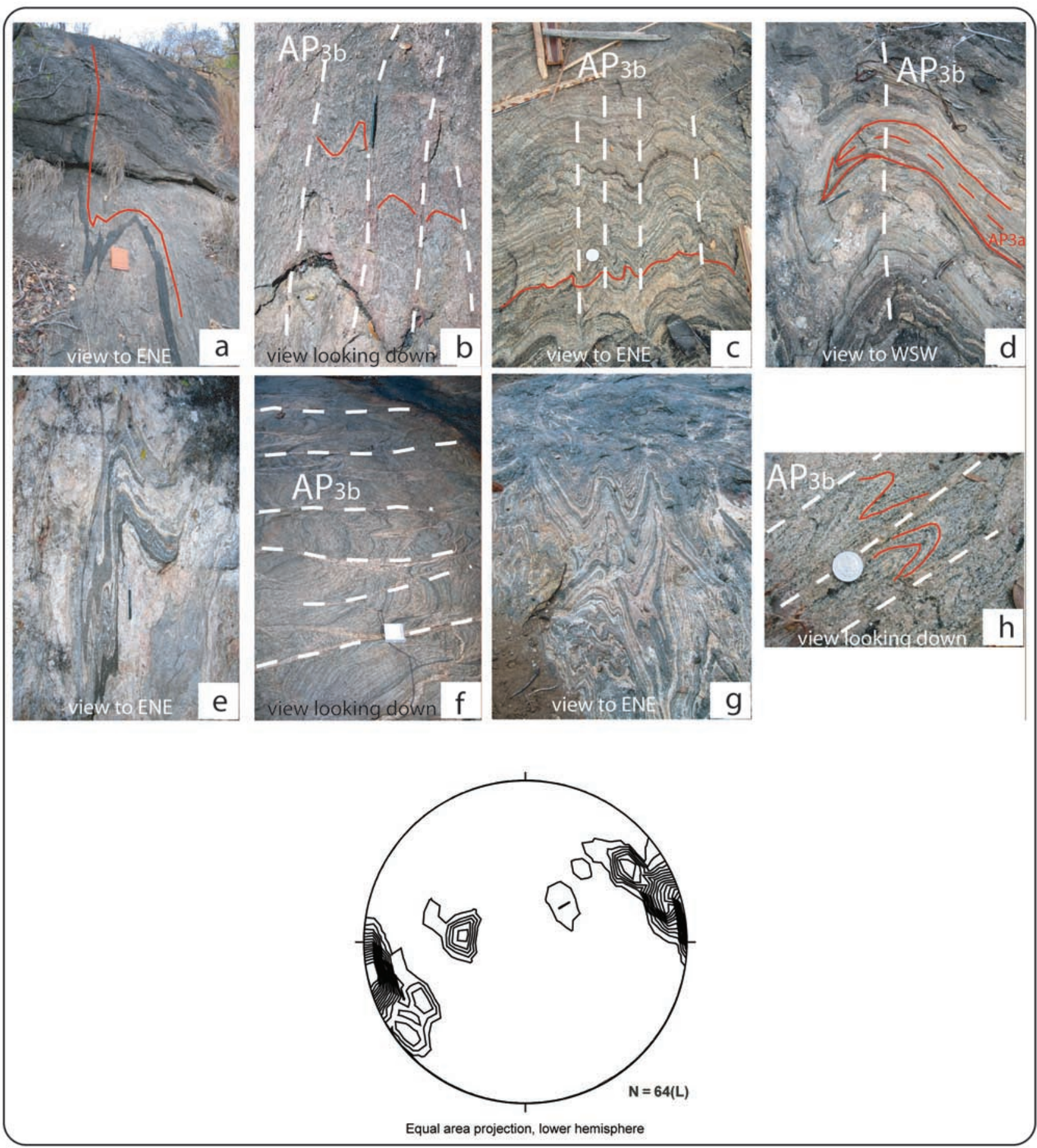

Figure 10. Stereonet: orientation of $\mathrm{F}_{3 \mathrm{~b}}$ fold axes in the western part of the Lurio Belt. (a) Amphibolitic layer folded around a WSW plunging axis. (b) Leucosome-injected axial plane cleavage of tight upright $\mathrm{F}_{3 \mathrm{~b}}$ folds. (c) Upright axial plane cleavage in banded biotite gneiss. (d) $\mathrm{F}_{3 \mathrm{a}}$ isoclinal fold refolded by a coaxial $F_{3 b}$ upright fold. (e) Upright, slightly asymmetric SW-NE trending $F_{3 b}$ folds deforming an amphibolite band. (f) Leucosome-injected, spaced axial planar cleavage to $F_{3 b}$ folds. (g) Train of upright $F_{3 b}$ folds. (h) Transposed isoclinal $F_{3 a}$ folds separated by leucosome injections along upright $F_{3 b}$ axial planes. 


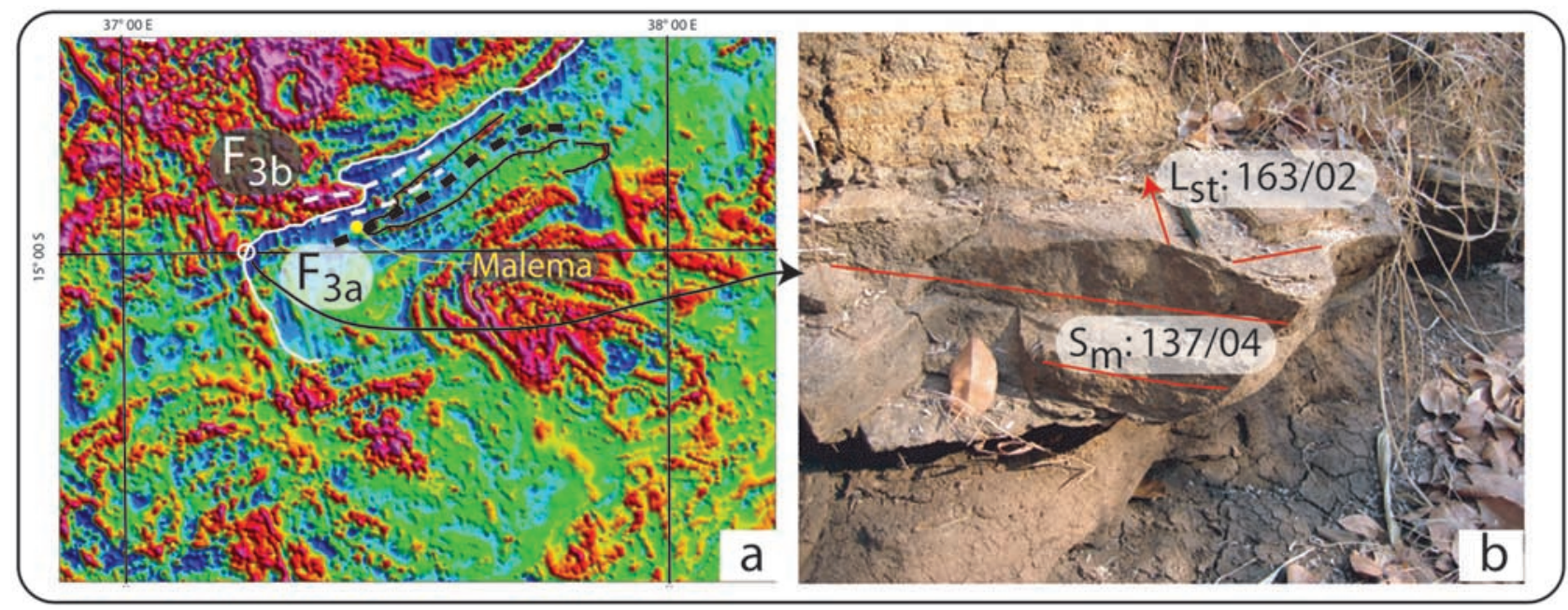

Figure 11. Interpretation of the available geophysical data covering the southwestern portion of the Lurio Belt. The SW plunging closure of a large-scale $\mathrm{F}_{3 \mathrm{~b}}$ fold is shown by the continuous white line, which corresponds to the interpreted southern boundary of the Lurio Belt as defined by the spatially continuous aeromagnetic low and the presence in the field of a highly sheared feldspar and quartz ribbon gneiss (see Figure 9). White dashed lines are $\mathrm{F}_{3 \mathrm{~b}}$ axial traces, whereas the black dashed line represents an earlier $\mathrm{F}_{3 \mathrm{a}}$ axial trace locally refolded by the younger $\mathrm{F}_{3 \mathrm{~b}}$ fold. (b) Outcrop of SE dipping Lurio Belt mylonites near the closure of the $\mathrm{F}_{3 \mathrm{~b}}$ fold shown in Figure 11a. Orientation data are in azimuthal annotation. The opposite dip to the normal NW dip of the Lurio Belt mylonites demonstrates that the mylonitic fabric is itself deformed by the $\mathrm{F}_{3 \mathrm{a}}$ and $\mathrm{b}$ folding history.

reworking of suitably oriented preexisting tectonic features. Clear examples are the attenuation (e.g., via asymmetric boudinage) and shear reworking, both sinistral and dextral, of preexisting tectonic contacts (e.g., Xixano-Marrupa) and the development of limited strike-slip imbricate structures to the north of the Lurio Belt within the Xixano Complex. The systematic inversion of sense of shear across-fold hinges is interpreted as being due to flexural flow folding mechanisms, whereby the strong mechanical anisotropy caused by the layering of the CDNC involved in the folding accommodated strain along the limbs by interlayer oblique slip. We also suggest that the overall sinistral shear corridor observed in the Nampula Complex immediately to the south of the Lurio Belt in the Ribáuè-Malema area may reflect local components of oblique simple shear accommodated during folding of the nappe sequence [Norconsult Consortium, 2007a].

[36] $F_{3 a}$ and $F_{3 b}$ folds are superposed on earlier $F_{2}$ isoclinal, NW plunging folds characteristic of the $\mathrm{D}_{2}$ Lurio deformation phase. Their geometrical superposition generates type II interference patterns, visible within the Lurio Belt and its immediate surroundings (Figure 12). "Eye structures" are common in the area (Figures 12a and 12b) and are usually interpreted as representing the intersection of topography with sheath folds. However, we rather interpret these as being due to the refolding of northwest plunging tight to isoclinal $F_{2}$ folds by $F_{3 a}$ and $F_{3 b}$ folds. Additionally, classic mushroom-type interference figures are recognized at all scales (Figures 12a, 12c, and 12d).

[37] Geochronological results bracket the age of this phase of regional folding accommodated compression between $586 \pm 4$ and $532 \pm 13 \mathrm{Ma}$ [Norconsult Consortium, 2007a]. The upper age constraint is inferred from a $586 \pm$
4 Ma old leucosome (sample 98DJ27A [Jamal, 2005]), probably formed during regional metamorphism associated with nappe stacking, and folded by the later NE-SW trending folds. The minimum age is constrained by the age of a synkinematic interboudin pegmatite related to the subsequent extensional tectonic phase (described in detail below). 4.3.2. Eastern Lurio Belt

[38] Going east along the Lurio Belt, the planar fabric progressively intensifies and the eastern segment of the belt is characterized by a $\sim 20 \mathrm{~km}$ wide zone of strong, moderately to steeply NNW and north dipping planar, mylonitic fabric with an orientation swinging from WSW-ESE in the west to $\mathrm{E}-\mathrm{W}$ in the east, corresponding to the overall local orientation of the belt (Figure 7). As was shown above, whereas the linear fabrics for the western part of the Lurio Belt are mostly downdip, predominantly crenulation axes and cannot be related to a specific kinematics (Figure 7), the data set from the easternmost part of the belt comprises true stretching lineations mostly related to strike-slip movement on the NNW to north dipping foliation planes. Lineations form two strong clusters plunging shallowly ENE and WSW. However, a limited number of generally downdip, more steeply NW plunging mineral stretching lineations are also observed (open circles in the stereonet of linear elements of the eastern Lurio Belt in Figure 7). This suite of stretching lineations is interpreted here as being related to a later phase of ductile extension $\left(\mathrm{D}_{5}\right)$, discussed below.

\subsection{Pan-African Bulk Regional Crustal Flattening}

[39] Field structural analysis and geophysical data allowed the identification of other important, later struc- 


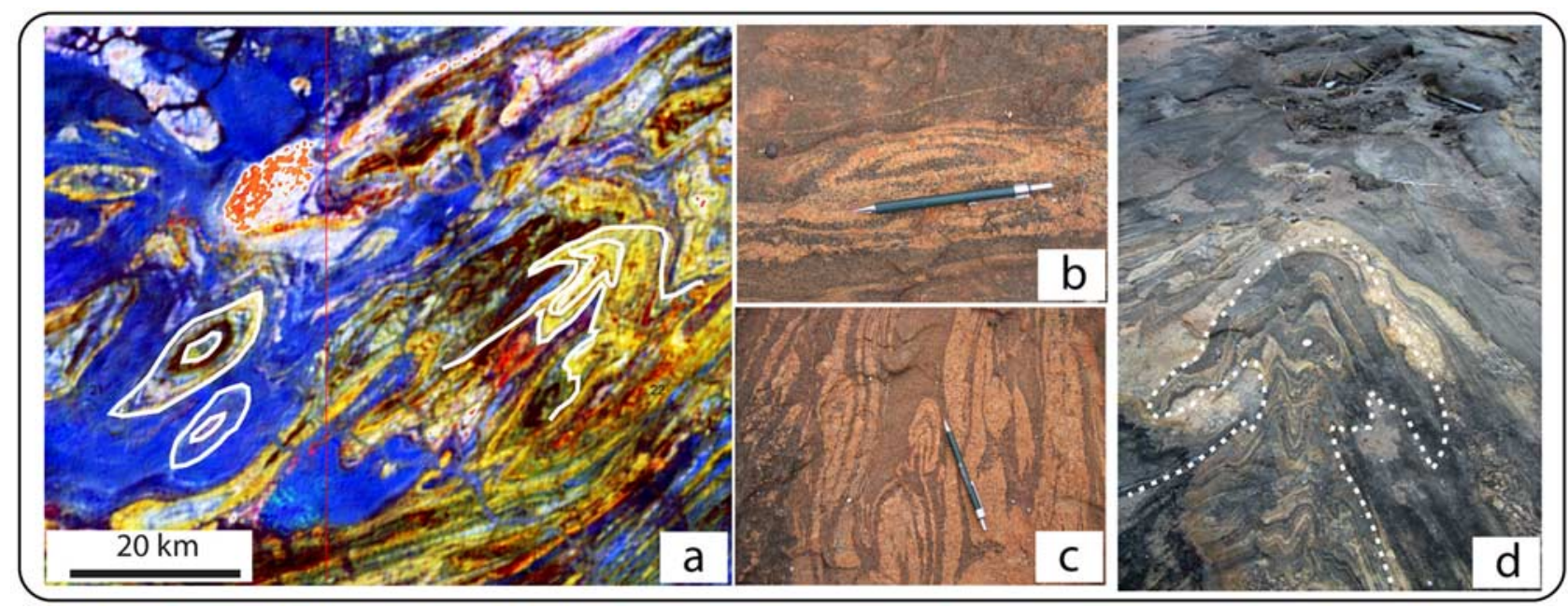

Figure 12. Type II interference figures in the Lurio Belt area. (a) Ternary image of radiometric data for survey blocks 4 and 5 over the northern part of the Lurio Belt showing large-scale type II interference figures (red, potassium; green, potassium/thorium; blue, potassium/uranium). The ellipsoidal "eye structures" are interpreted as being due to the intersection between topography and the interference geometry generated by refolding of NW plunging tight to isoclinal $F_{2}$ folds by $F_{3 a}$ and $F_{3 b}$ folds and not as sheath folds. These features, together with classic "mushroom interference patterns" are recognized at all scales, as shown in Figures 12a, 12b, 12c, and 12d.

tures, predominantly within the eastern Lurio Belt. Because of their isoclinal geometry, the $\mathrm{F}_{3 \mathrm{a}}$ folds that characterize the Lurio Belt must have reached a lock-up and strain hardening stage. Ongoing shortening, orthogonal to the strike of the belt and to the $\mathrm{F}_{3 \mathrm{a}}$ fold axial planes, was thus accommodated by open coaxial folds (F 3b) and by the development of megascopic sets of conjugate ductile shear zones $\left(D_{4}\right)$. The previous section pointed out that the Lurio Belt does not, on a map scale, display a linear geometry over its entire length, but presents instead a major change in strike in the east, where the belt swings to an east-west trend. Also, the eastern sector of the belt is more continuous, displays a very pervasive mylonitic fabric and lacks the structural segmentation typical of the western part, where Ocua lithologies are highly dismembered along the belt.

[40] Field observations in the eastern Lurio Belt area have led to the identification of numerous small-scale to megascale, steep dextral and sinistral shear zones, striking eastwest and NNE-SSW, respectively (insets in Figure 13). The new geophysical data for the same eastern portion of the Lurio Belt, where the strike swing occurs, show an important set of map-scale conjugate shear zones (Figure 13). These are oriented east-west and NNE-SSW, identical to the two sets of opposed kinematics shear zone sets observed in the field. Clear kinematic indicators (sigmoidal deflection of the external foliation, asymmetric clasts and asymmetric folds) indicate their dextral and sinistral sense of shear, respectively.

[41] Figure 14a shows a genetic model for the development of these late $\mathrm{D}_{4}$ structural features, in which they formed in response to the accommodation of a bulk subhorizontal shortening component oriented NW-SE. We therefore interpret these shear zones to be the result of the same progressive shortening event that, with a maximum compressive direction oriented NW-SE, also produced the $\mathrm{F}_{3}$ folds. Such conjugate ductile shear zones with opposing senses of shear, deforming the original Lurio mylonitic structure, are a natural consequence of orthogonal shortening and progressive pure shear deformation in the Lurio Belt. Strain accommodation within the belt (via isoclinal folding and conjugate shear zones) is more intense than in the surrounding blocks (open to tight folding and conjugate shear zones) probably because of the existence of older inherited structures (possibly the Grenvillian age boundary between the Nampula and Marrupa-Unango complexes) acting as a zone of mechanical weakness and leading to preferential strain accommodation and fold amplification. Thus, the eastern sector of the Lurio Belt, where the overall structural grain swings to an east-west orientation, reflects the local, strong control of such an east-west trending ductile shear zone (clearly seen in Figures 13 and 14b).

[42] As shown in Figure 14b, conjugate sets of shear zones with similar orientation and kinematics to that observed in the eastern Lurio Belt can be recognized at the regional scale. The aereomagnetic data for part of the area mapped and also for the part of the Nampula Complex mapped by the Council for Geoscience of South Africa indicate several conjugate shear zones. It is interesting to observe that the Namama belt [Cadoppi et al., 1987; Macey et al., 2007] is a major sinistral shear belt, the orientation and kinematics of which suggest that it is also part of the same set of conjugate structures that accommodated NWSE oriented pure shear (Figure 14b). If this is the case, the Namama Belt is a Pan-African structure and not older as postulated by Cadoppi et al. [1987]. In addition, Fritz et al. [2005] describe shear zones in southern Tanzania with 


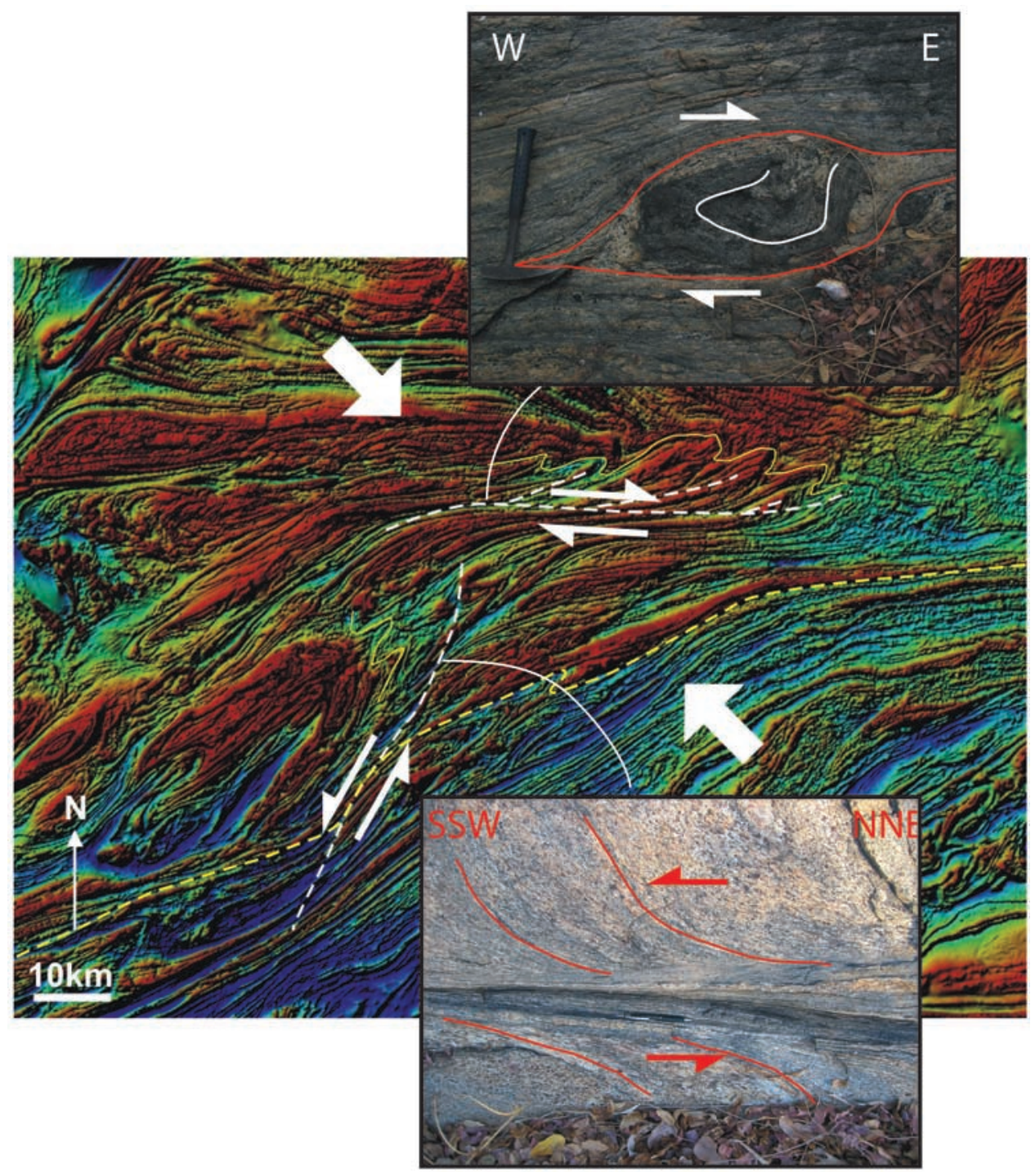

Figure 13. Total magnetic field anomaly data, survey blocks 4 and 5, over part of the eastern Lurio Belt. Color shaded relief presentation with a virtual light source in the NE. Regional-scale shear zones $\left(\mathrm{D}_{4}\right)$ with opposing senses of shear define a set of conjugate structures that accommodated pure shear due to NW-SE shortening (large white arrows). Asymmetric synkinematic folds $\left(\mathrm{F}_{4} ; \mathrm{SW}\right.$ and east vergent; outlined by the yellow lines), together with the asymmetry of external fabrics dragged into the trend of the shear zones, confirm the overall sense of shear for the conjugate shear zones. These shear zones are also seen on the ground with opposing senses of shear, dextral for the E-W trending shears (upper inset) and sinistral for the NNE-SSW trending structures (bottom inset). Both photographs are taken looking down on subhorizontal pavements. Note the presence of an earlier fold in the mesoscale dextral sigma clast of the upper inset (white line).

identical orientation and kinematics, possibly suggesting an even broader regional extent for these structures.

[43] In the absence of direct geochronological constraints, the development of these conjugate shear zones is bracketed between 586 and $532 \mathrm{Ma}$, the same age interval as defined for the folding episode. Nonetheless, the event must postdate the formation, tightening and locking up of the Lurio $\mathrm{F}_{3 \mathrm{a}}$ isoclinal folds. As clearly visible in Figure 13, the $\mathrm{E}-\mathrm{W}$ trending dextral and the NNE-SSW trending sinistral shear zones cut through and transpose tight to isoclinal $\mathrm{F}_{3 \mathrm{a}}$ upright folds with axial planes perpendicular to the reconstructed shortening direction.

\subsection{NW-SE Syn- to Late Pan-African Crustal Extension}

[44] Postdating the crustal shortening episode terminated with the $\mathrm{F}_{3 \mathrm{~b}}$ folding phase and the development of $\mathrm{D}_{4}$ pure shear accommodating shear zones, there is a phase of approximately NW-SE extension, characterized by shear- 

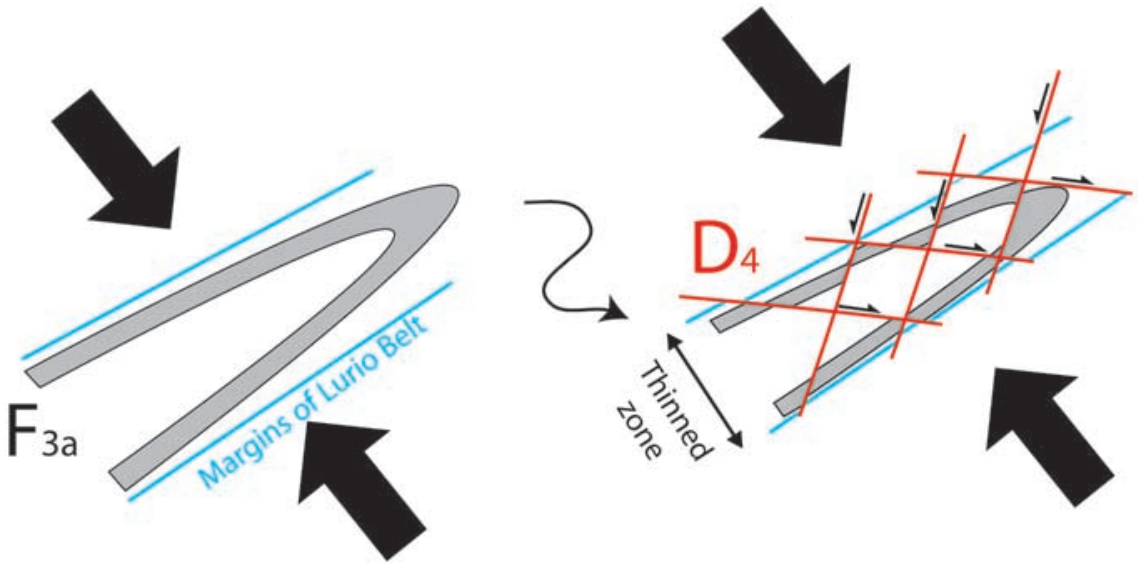

\section{a}

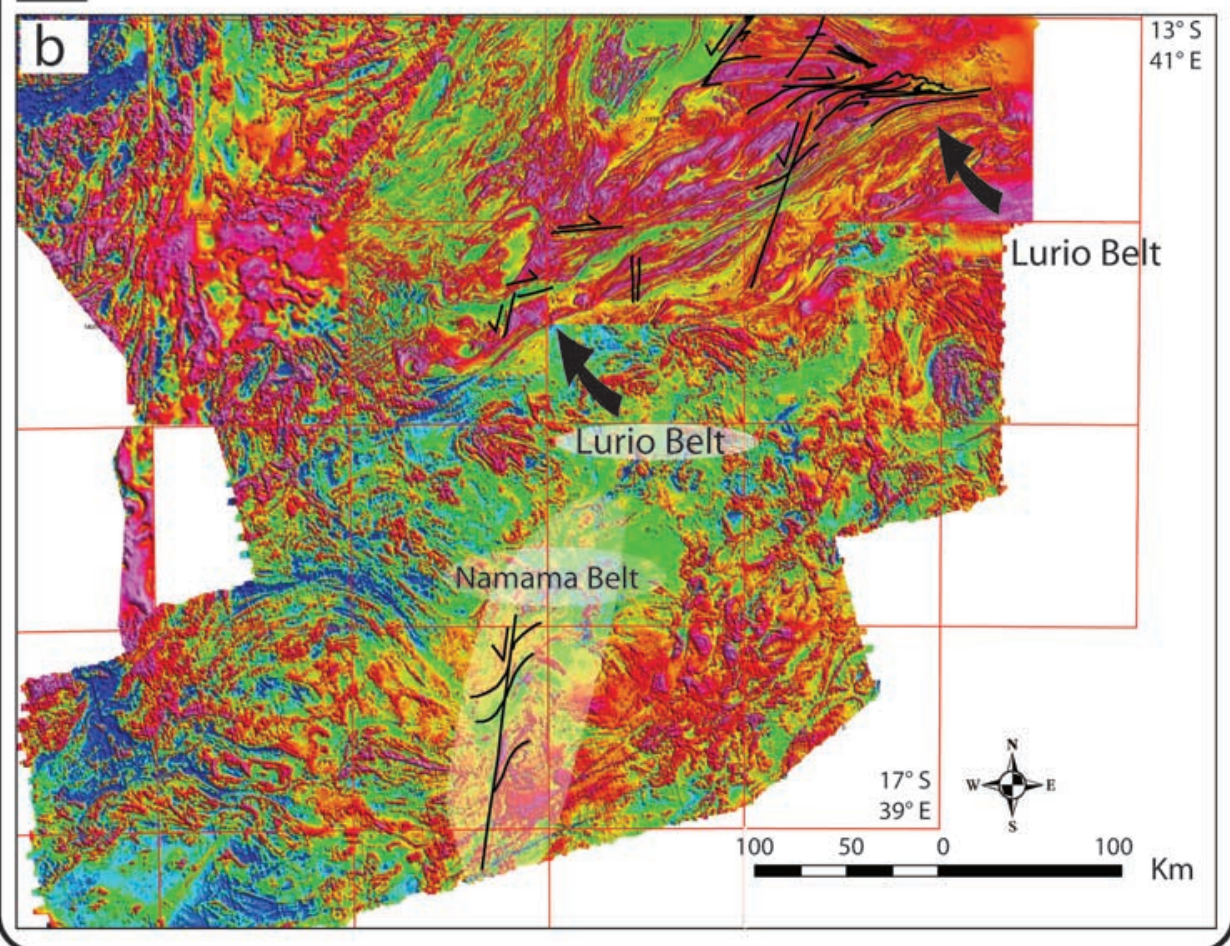

Figure 14. Model for the formation of $\mathrm{D}_{4}$, late Pan-African conjugate shear zones in the Lurio Belt. (a) Schematic diagram showing the progressive deformation of the Lurio Belt during SE-NW directed compression. The $\mathrm{F}_{3 \mathrm{a}}$ WSW-ENE isoclinal folds are increasingly attenuated. Strain hardening eventually leads to the development of sets of conjugate dextral and sinistral ductile shear zones striking NNE-SSW and approximately $\mathrm{E}-\mathrm{W}$. These have opposing senses of shear, which allow continued flattening across the belt. They effectively thin and attenuate the whole Lurio Belt and modify its tectonic borders. (b) Conjugate shear zones are also seen outside the Lurio Belt and can be recognized as far south as the Namama Belt [Macey et al., 2007] and at least as far north as the Tanzanian border, with the same orientation and opposing senses of shear, suggesting that they are structures of regional importance. 


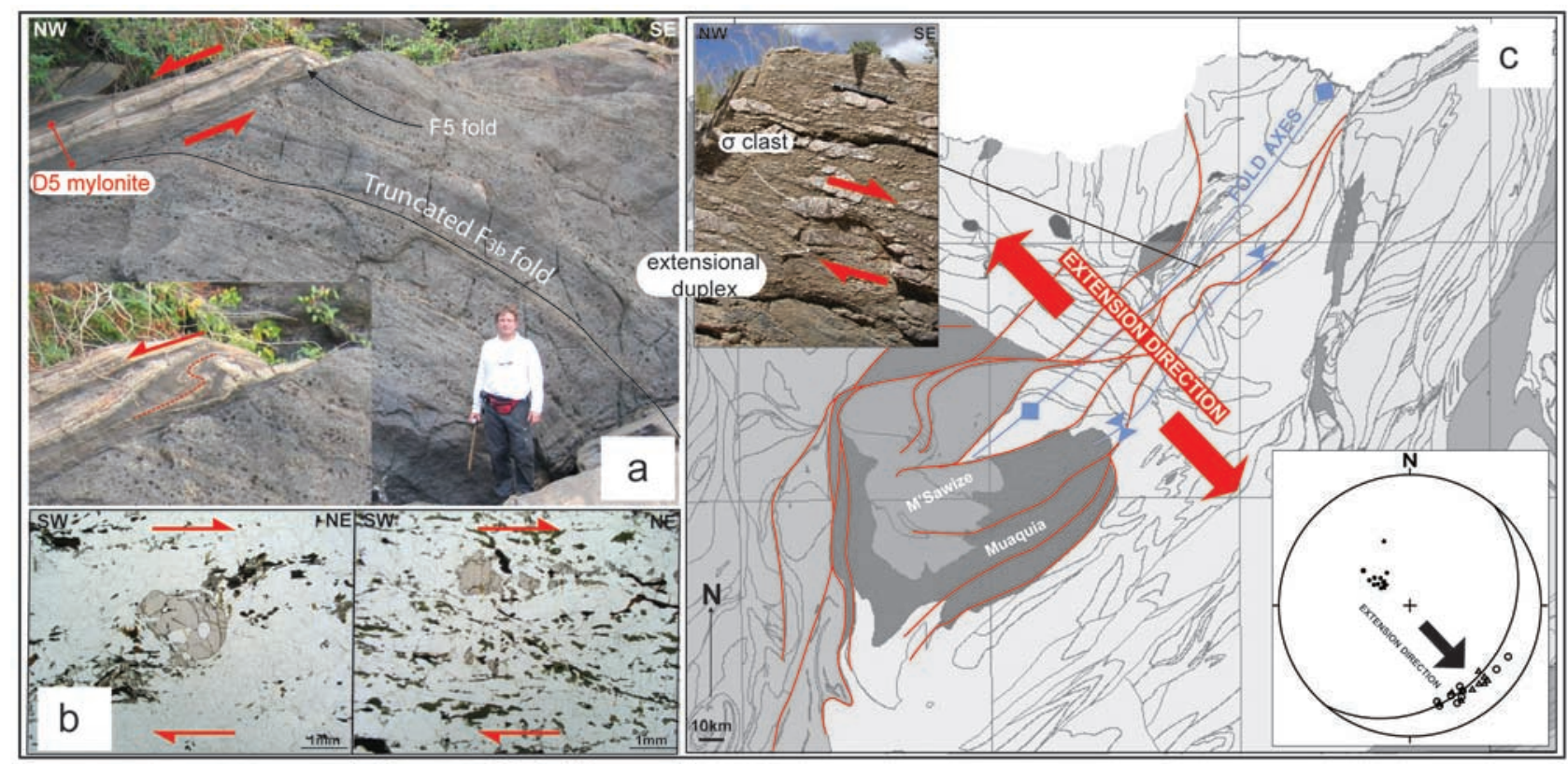

Figure 15. Evidence for discrete $\mathrm{D}_{5}$ extensional mylonitic shear zones. (a) NW dipping shear zone cutting an $\mathrm{F}_{3 \mathrm{~b}}$ fold and displaying extensional kinematics (UTM 37S, 608709, 8506268). The inset shows an asymmetric $F_{5}$ fold within the shear zone. (b) Photomicrographs of garnet porphyroclasts from extensional mylonites. These show sigma tails containing both orthopyroxene and clinopyroxene confirming that the shear zones started to develop under granulite facies conditions. (c) A $80 \mathrm{~km}$ wide and $300 \mathrm{~km}$ long zone of anastomosing, regional-scale extensional shear zones has been mapped from integrated field observations and geophysical interpretation. These shear zones are up to $50 \mathrm{~m}$ wide and contain a variety of consistent kinematic indicators indicating top-to-the-SE extensional kinematics. The stereonet in the inset plots the mylonitic foliation orientation (solid circles, poles to foliation, and great circle, average orientation), stretching lineation (open circles) and mullions (triangles).

ing along localized, discrete shear zones $\left(\mathrm{D}_{5}\right)$. Discrete topto-the-NW extensional ductile shear zones are recognized extensively within the eastern Lurio Belt and in a broad zone to the north extending at least to the Tanzanian border, beyond which such late Pan-African structures have not yet been recognized or reported. The extensional mylonite zones range from the centimeter scale up to $20 \mathrm{~m}$ in thickness and dip generally NW, with downdip stretching lineations. Although kinematic indicators are sparse, asymmetric clasts, shear bands and small asymmetric NW vergent folds $\left(\mathrm{F}_{5}\right.$ in our scheme) indicate top-to-the-NW extension (Figure 15a and its inset). The metamorphic grade of these extensional ductile shear zones is noteworthy in the context of the presumed waning of high PT metamorphic conditions at the end of the Pan-African orogeny. Both granulite and amphibolite facies assemblages are observed within these mylonitic fabrics (Figure 15b), for example in asymmetric pressure shadows related to sigma clasts and extensional crenulation cleavage. This suggests that the extensional mylonitic structures developed during the latest stages of high-pressure metamorphism and ultimately led to the exhumation of these high-grade rocks.

[45] Although discrete extensional mylonitic bands within the Lurio Belt are generally difficult to map as continuous structures due to the scarcity of outcrop and the parallelism between the mylonitic foliation of the belt and the exten- sional shear zones, the recognition of such structures outside the belt is generally more straightforward, primarily due to their obliquity to the earlier regional fabrics and to their crosscutting relationship to the individual nappe contacts of the CDNC (Figure 15c). Significant extension was found to be concentrated, for example, in an approximately $80 \mathrm{~km}$ wide, NE-SW striking zone, which has a mappable strike length of over $300 \mathrm{~km}$, some $150 \mathrm{~km} \mathrm{NW}$ of the northern margin of, and subparallel to, the Lurio Belt (Figure 15c). These extensional structures cut through the preextension tectonostratigraphy, which allows them to be easily mapped and identified as regionally important features. At outcrop scale, individual shear zones are often up to $50 \mathrm{~m}$ wide and consist of very strongly sheared mylonites, with megasigma clasts, extensional crenulation cleavages and extensional duplexes (Figure 15c and its insets) showing conjugate top-to-the-SE and -NW extensional displacement.

[46] Extensional fabrics are observed over a large area and are not invariably linked to regional-scale, laterally continuous shear zones. They are often found overprinting and partially reactivating earlier, small-scale mylonitic structures, particularly within the Lurio Belt and in an area $15-20 \mathrm{~km}$ to the north of it. Asymmetric pporphyroblasts (Figures 16a and 16b), asymmetric $\mathrm{F}_{5}$ folds (Figure 16c) and biotite-stable extensional crenulation cleavages (Figure 16d) point to generally downdip, top-to-the-NW shearing. 


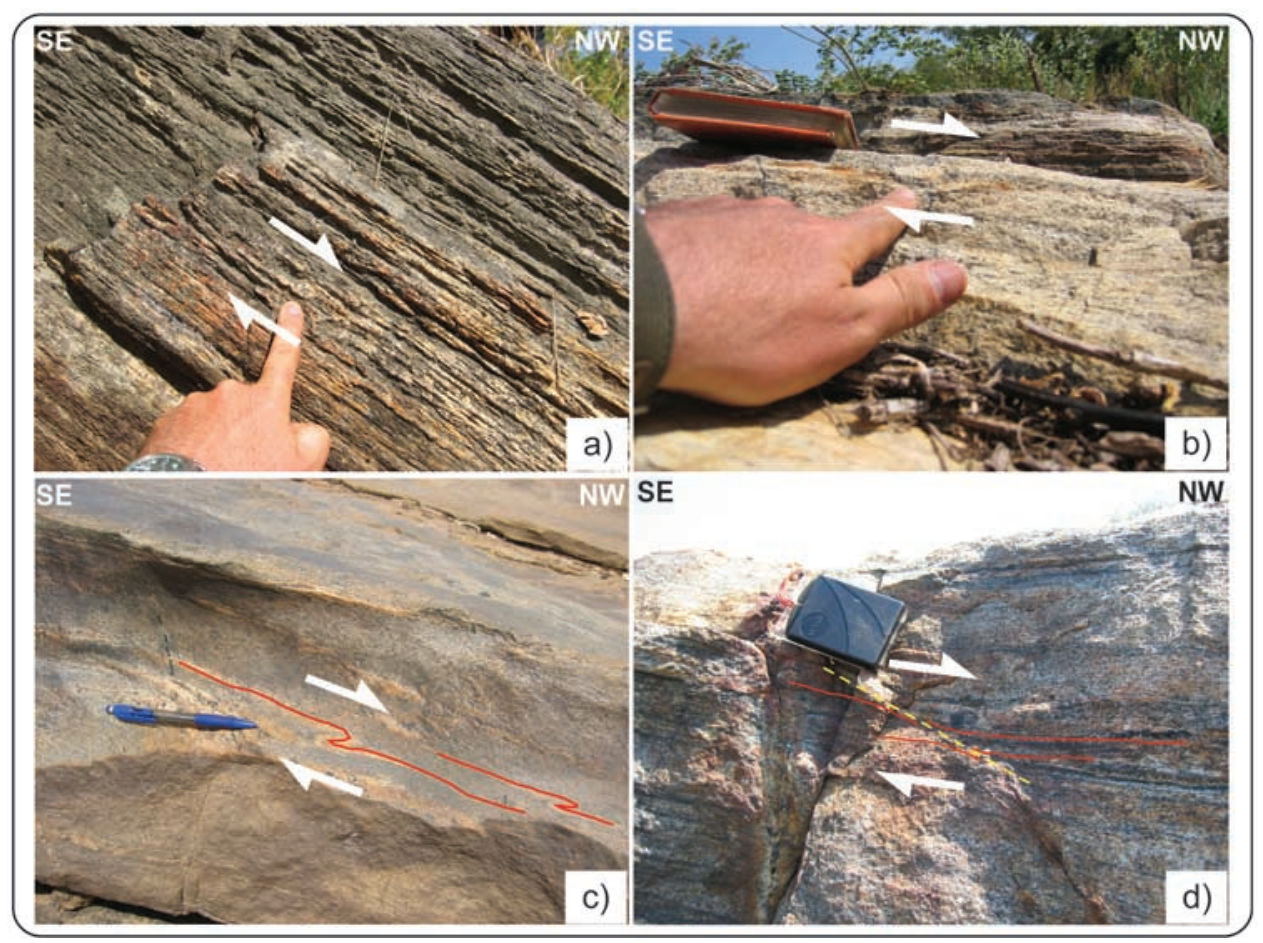

Figure 16. Examples of ductile extensional fabrics and kinematic indicators to the north of the Lurio Belt. These are (a) sigma clasts, (b) oblique fabrics, (c) asymmetric NW vergent folds, and (d) small-scale extensional shear bands.

[47] In the area to the south of the Lurio Belt, although it has only been minimally covered by us [Norconsult Consortium, 2007a], there is no convincing evidence for extensional structures; neither were explicit extensional structures observed and reported from the Nampula Complex farther to the south [e.g., Macey et al., 2007]. This suggests that either the zone of extension is highly asymmetric and is skewed to the north of the Lurio Belt and most likely stops abruptly at its southern margin or that the field evidence is very unevenly preserved, possibly reflecting different amounts of exhumation north and south of the Lurio Belt. The asymmetry could also be a reflection of strain partitioning, whereby the localization of previous deformation episodes, which are concentrated north of the Lurio Belt (e.g., $\mathrm{F}_{3 \mathrm{a}}$ folds located preferentially within and intensifying toward, the Lurio Belt) also controlled the spatial distribution of the later extensional fabrics. The extensional structures have in all likelihood reused the intense mylonitic structures associated with nappe stacking, nappe stack folding, regional flattening and conjugate reactivation given their lowered mechanical strength as previously attenuated deformation zones. This is consistent with the more extensive preservation of the CDNC north of the Lurio Belt.

\section{Geochronology of the Extension Event}

[48] In terms of timing of the extensional episode, in general, the extensional mylonites clearly crosscut contacts with $F_{3 b}$ folds which they truncate sharply (Figure 15a).
This observation can in turn be used to indirectly constrain extension as postdating the tightening of the regional folds and their subsequent lateral segmentation. In the Lurio Belt, a garnet-clinopyroxene mafic gneiss was observed to be boudinaged along the top-to-the-NW extensional shear zone of Figure 15a. Boudin necks are infilled by synkinematic granite pegmatite. A sample of pegmatite (grain size $\sim 10 \mathrm{~mm}$ ) was collected for geochronology (sample 33312-BB062) in $\mathrm{a} \sim 20 \mathrm{~cm}$ large boudin neck. The rock is rich in plagioclase, quartz and scapolite. Zircon is abundant and forms large (commonly $>300 \mu \mathrm{m}$ ) oscillatory-zoned prismatic crystals with well terminated pyramids. The 32 LA-ICMPS analyses were performed in 10 zircon crystals (Table 1 and Figure 17a). With the available instrumentation, laser-ablation-related element fractionation is unavoidable, explaining the average position of the data points above the concordia curve. With this limitation, the ${ }^{207} \mathrm{~Pb} /{ }^{206} \mathrm{~Pb}$ age is the best estimate for the timing of crystallization of a zircon. The analyses yield a weighted average ${ }^{207} \mathrm{~Pb} /{ }^{206} \mathrm{~Pb}$ age of $532 \pm 13 \mathrm{Ma}(\mathrm{MSWD}=$ 0.84 ; Figure 17a), dating the crystallization of the pegmatite infill and the post $F_{3 b}$ extension in this outcrop. The extensional shear zone itself is made up of a banded gneiss with strong planar fabric. A felsic layer was sampled in this banded gneiss (sample 33310-BB060). Highly strained $\mathrm{K}$-feldspar and garnet porphyroclasts as well as quartz ribbons attest to the high shear strain in this rock. Monazite is observed as tabular crystals parallel to the mylonitic foliation. 34 analyses in 14 monazite crystals yielded a weighted average ${ }^{207} \mathrm{~Pb} /{ }^{206} \mathrm{~Pb}$ age of $540 \pm 7 \mathrm{Ma}$ (MSWD = 0.93 ), dating crystallization or recrystallization of the mon- 
Table 1. LA-ICPMS U-Pb Data for Zircons From Boudin Neck Pegmatite, Sample 33312-BB062, Zircon

\begin{tabular}{|c|c|c|c|c|c|c|c|c|c|c|c|c|c|}
\hline $\mathrm{ID}^{\mathrm{a}}$ & $\begin{array}{l}{ }^{206} \mathrm{~Pb} / \\
{ }^{204} \mathrm{~Pb}^{\mathrm{b}}\end{array}$ & $\begin{array}{l}{ }^{207} \mathrm{~Pb} / \\
{ }^{206} \mathrm{~Pb}^{\mathrm{c}}\end{array}$ & $\begin{array}{l}1 \sigma \\
(\%)\end{array}$ & $\begin{array}{l}{ }^{207} \mathrm{~Pb} / \\
{ }^{235} \mathrm{U}^{\mathrm{c}}\end{array}$ & $\begin{array}{l}1 \sigma \\
(\%)\end{array}$ & $\begin{array}{l}{ }^{206} \mathrm{~Pb} / \\
{ }^{238} \mathrm{U}^{\mathrm{c}}\end{array}$ & $\begin{array}{l}1 \sigma \\
(\%)\end{array}$ & $\mathrm{Co}^{\mathrm{d}}$ & $\begin{array}{c}{ }^{206} \mathrm{~Pb} /{ }^{238} \mathrm{U}^{\mathrm{e}} \\
(\mathrm{Ma})\end{array}$ & $\begin{array}{l}1 \sigma \\
(\%)\end{array}$ & $\begin{array}{c}{ }^{207} \mathrm{~Pb} /{ }^{206} \mathrm{~Pb}^{\mathrm{e}} \\
(\mathrm{Ma})\end{array}$ & $\begin{array}{l}1 \sigma \\
(\%)\end{array}$ & $\begin{array}{l}\mathrm{Di}^{\mathrm{f}} \\
(\%)\end{array}$ \\
\hline 30 & 1476 & 0.05946 & 2.9 & 0.6356 & 3.0 & 0.07753 & 0.7 & 0.22 & 481 & 3 & 584 & 63 & 18 \\
\hline 31 & 2333 & 0.05610 & 2.7 & 0.6247 & 2.8 & 0.08076 & 0.9 & 0.32 & 501 & 4 & 456 & 59 & -9.7 \\
\hline 24 & 15121 & 0.05820 & 0.8 & 0.6618 & 1.1 & 0.08247 & 0.7 & 0.68 & 511 & 4 & 537 & 18 & 4.9 \\
\hline $21 x$ & 1907 & 0.05425 & 2.8 & 0.6222 & 2.8 & 0.08319 & 0.7 & 0.25 & 515 & 3 & 381 & 62 & -35 \\
\hline 25 & 61087 & 0.05901 & 1.0 & 0.6802 & 1.2 & 0.08360 & 0.7 & 0.57 & 518 & 3 & 567 & 22 & 8.8 \\
\hline 32 & 7628 & 0.05863 & 2.6 & 0.6940 & 2.7 & 0.08584 & 0.8 & 0.29 & 531 & 4 & 553 & 57 & 4.1 \\
\hline 47 & 24925 & 0.05836 & 1.7 & 0.6948 & 2.0 & 0.08634 & 1.0 & 0.49 & 534 & 5 & 543 & 37 & 1.7 \\
\hline 51 & 8426 & 0.05702 & 2.6 & 0.6874 & 2.9 & 0.08744 & 1.3 & 0.45 & 540 & 7 & 492 & 58 & -9.8 \\
\hline 08 & 5513 & 0.05745 & 1.8 & 0.6960 & 2.1 & 0.08785 & 1.1 & 0.53 & 543 & 6 & 509 & 39 & -6.7 \\
\hline 44 & 9120 & 0.05834 & 1.6 & 0.7108 & 2.0 & 0.08836 & 1.2 & 0.61 & 546 & 7 & 543 & 35 & -0.6 \\
\hline 22 & 6983 & 0.05691 & 2.1 & 0.6963 & 2.2 & 0.08873 & 0.7 & 0.31 & 548 & 4 & 488 & 46 & -12 \\
\hline 13 & 2512 & 0.05880 & 3.4 & 0.7234 & 3.5 & 0.08922 & 1.0 & 0.28 & 551 & 5 & 560 & 74 & 1.6 \\
\hline 01 & 2015 & 0.05627 & 2.1 & 0.6942 & 2.2 & 0.08948 & 0.8 & 0.37 & 552 & 4 & 463 & 46 & -19 \\
\hline 34 & 13948 & 0.05766 & 2.2 & 0.7122 & 2.3 & 0.08959 & 0.6 & 0.28 & 553 & 3 & 517 & 48 & -7.0 \\
\hline 28 & 22160 & 0.05849 & 2.1 & 0.7227 & 2.2 & 0.08962 & 0.8 & 0.35 & 553 & 4 & 548 & 45 & -1.0 \\
\hline 50 & 22422 & 0.05887 & 1.9 & 0.7275 & 2.1 & 0.08962 & 0.9 & 0.42 & 553 & 5 & 562 & 42 & 1.6 \\
\hline 04 & 6587 & 0.05685 & 1.1 & 0.7075 & 1.4 & 0.09026 & 0.9 & 0.66 & 557 & 5 & 486 & 24 & -15 \\
\hline 27 & 18362 & 0.05848 & 2.8 & 0.7284 & 2.9 & 0.09034 & 0.7 & 0.23 & 558 & 4 & 548 & 62 & -1.8 \\
\hline 42 & 5748 & 0.05787 & 2.9 & 0.7234 & 3.2 & 0.09067 & 1.3 & 0.40 & 559 & 7 & 525 & 64 & -6.6 \\
\hline 03 & 3218 & 0.05792 & 2.1 & 0.7250 & 2.4 & 0.09078 & 1.0 & 0.42 & 560 & 5 & 527 & 47 & -6.3 \\
\hline 23 & 24178 & 0.05937 & 2.4 & 0.7465 & 2.5 & 0.09120 & 0.6 & 0.25 & 563 & 3 & 581 & 52 & 3.1 \\
\hline $02 x$ & 2489 & 0.05541 & 2.0 & 0.6972 & 2.2 & 0.09126 & 0.8 & 0.36 & 563 & 4 & 429 & 45 & -31 \\
\hline 33 & 31429 & 0.05794 & 2.0 & 0.7326 & 2.1 & 0.09171 & 0.8 & 0.35 & 566 & 4 & 527 & 44 & -7.3 \\
\hline 45 & 11856 & 0.05717 & 2.4 & 0.7240 & 2.9 & 0.09185 & 1.6 & 0.55 & 566 & 9 & 498 & 53 & -14 \\
\hline 48 & 6627 & 0.05720 & 2.4 & 0.7255 & 2.8 & 0.09198 & 1.4 & 0.50 & 567 & 8 & 499 & 54 & -14 \\
\hline 10 & 792238 & 0.06039 & 1.7 & 0.7706 & 2.0 & 0.09255 & 1.0 & 0.49 & 571 & 5 & 618 & 37 & 7.6 \\
\hline 06 & 7964 & 0.05824 & 1.3 & 0.7447 & 1.7 & 0.09274 & 1.1 & 0.67 & 572 & 6 & 539 & 27 & -6.1 \\
\hline 43 & 3594 & 0.05600 & 2.3 & 0.7237 & 2.7 & 0.09372 & 1.5 & 0.54 & 578 & 8 & 452 & 51 & -28 \\
\hline $29 x$ & 2905 & 0.05453 & 2.2 & 0.7050 & 2.4 & 0.09377 & 0.9 & 0.38 & 578 & 5 & 393 & 49 & -47 \\
\hline 35 & 43704 & 0.05791 & 2.1 & 0.7489 & 2.2 & 0.09380 & 0.6 & 0.27 & 578 & 3 & 526 & 45 & -9.8 \\
\hline 49 & 29230 & 0.05869 & 2.0 & 0.7610 & 2.6 & 0.09404 & 1.6 & 0.62 & 579 & 9 & 556 & 44 & -4.3 \\
\hline 05 & 27839 & 0.05876 & 1.1 & 0.7667 & 1.4 & 0.09463 & 0.8 & 0.60 & 583 & 5 & 558 & 24 & -4.4 \\
\hline 14 & 6903 & 0.05755 & 1.7 & 0.7663 & 1.9 & 0.09657 & 0.9 & 0.47 & 594 & 5 & 513 & 37 & -16 \\
\hline 07 & 5923 & 0.05703 & 2.4 & 0.7696 & 2.6 & 0.09787 & 1.2 & 0.44 & 602 & 7 & 493 & 52 & -22 \\
\hline 36 & 19020 & 0.05786 & 2.3 & 0.7857 & 2.4 & 0.09848 & 0.7 & 0.31 & 606 & 4 & 525 & 50 & -15 \\
\hline
\end{tabular}

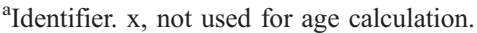

${ }^{\mathrm{b}}$ Measured ratio.

${ }^{\mathrm{c}}$ Ratio corrected for common $\mathrm{Pb}$.

${ }^{\mathrm{d}}$ Correlation of errors.

${ }^{\mathrm{e}}$ Age corrected for common $\mathrm{Pb}$.

${ }^{\mathrm{f}}$ Discordance of the analysis: $100-\left(100 \times\left({ }^{206} \mathrm{~Pb} /{ }^{238} \mathrm{U}\right)\right.$ age $/\left({ }^{207} \mathrm{~Pb} /{ }^{206} \mathrm{~Pb}\right)$ age $)$.

azite along the foliation plane (Table 2 and Figure 17b). The $540 \pm 7$ Ma monazite in the top-to-the-NW banded gneiss and the $532 \pm 13$ Ma boudin neck pegmatite yield overlapping ages, thus confirming the timing of extension at this outcrop.

[49] In summary, these new ages constrain a well-defined phase of crustal extension roughly coaxial with the prior compressional event. However, although we have a wellconstrained kinematic framework for late Pan-African extension, and, as we shall see below, our evidence fits remarkably well with the observations from other parts of the orogen, our geochronological data from structurally controlled extensional sites are still too scarce to allow the definition of a tightly constrained time framework for this event.

\section{Discussion}

\subsection{Foreland to the Cabo Delgado Nappe Complex}

[50] Figure 18 shows a sketch NW-SE cross section across the study area that serves the purpose of clarifying and illustrating the geometric/kinematic relationships of the main tectonostratigraphic units identified. From the evidence discussed in this paper it is obvious that Pan-African deformation played a major role in shaping the crustal framework of the study area and that the present tectonostratigraphy is a direct result of it. Although superposed on presumably pervasive earlier fabrics and structures, PanAfrican tectonism overprinted the whole region to such an extent that we believe that significant, earlier structural and tectonic features are not extensively preserved north of the Lurio Belt. South of the Lurio Belt, in the Nampula Complex, polyphase Mesoproterozoic deformational and metamorphic events can be recognized. Notwithstanding this, however, the relative position of the various complexes within the regional tectonostratigraphy (as shown in Figure $1 \mathrm{~b}$ ) is predominantly the result of a Pan-African top-to-the-NW directed shortening event that caused nappe translation and imbrication within the CDNC fold and thrust belt. 


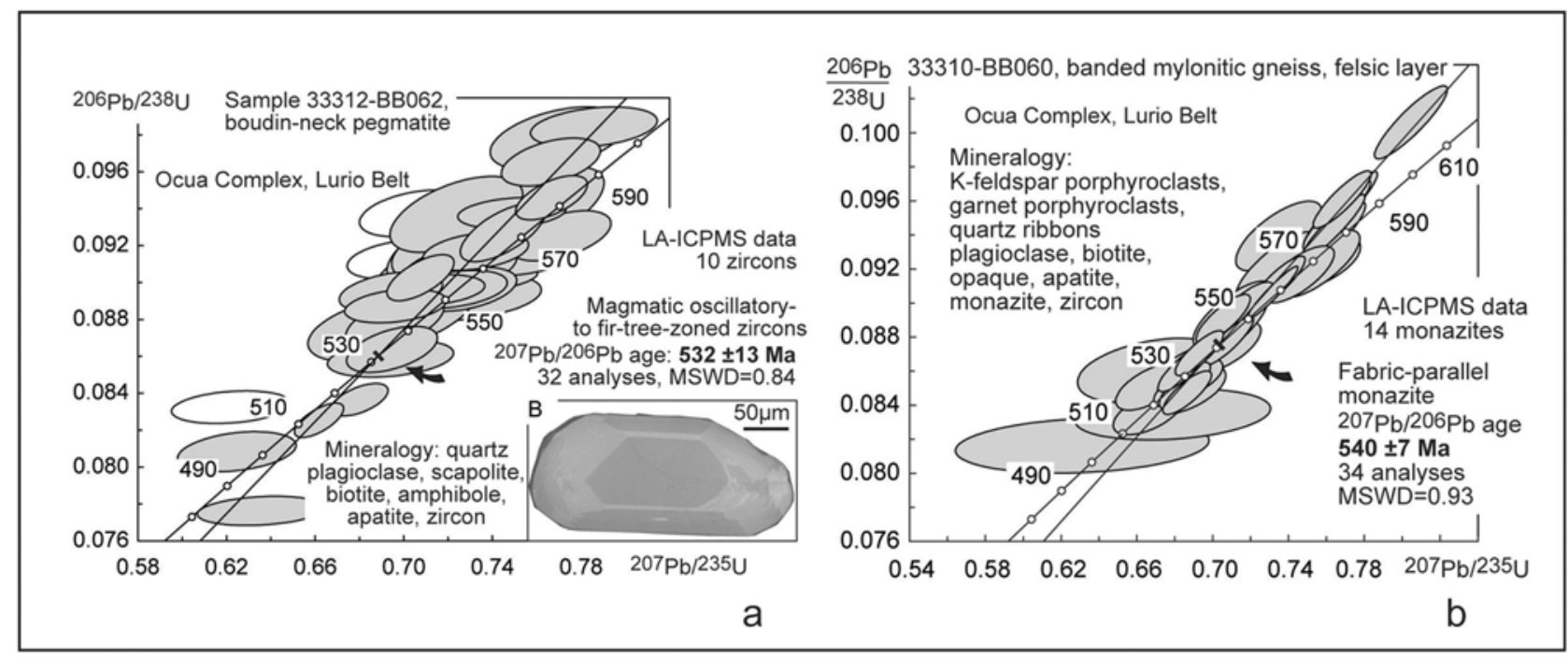

Figure 17. (a) Zircon $\mathrm{U}-\mathrm{Pb}$ data from a sample of interboudin pegmatite collected in the outcrop illustrated in Figure 15a, in the eastern Lurio Belt. Boudinage took place under top-to-the-NW extensional shearing. A concordia diagram and a CL image of a section through a typical zircon are included. The $532 \pm 13 \mathrm{Ma}$ age constrains extension in this sector of the orogen. (b) Monazite data from a sample of the mylonitic banded gneiss hosting the pegmatitic boudin that yielded the zircons of Figure 17a. The two ages are identical within the error limit.

[51] The Ponta Messuli Complex, exposed only in a small area in NE Mozambique, is here interpreted as forming the NW foreland of the CDNC, in the same way as the Congo-Tanzanian craton is interpreted as the foreland of the East African Orogen in Tanzania [Stern, 1994]. The Ponta Messuli Complex lacks a high-grade Pan-African overprint. Paragneisses in this complex contain detrital zircons ranging from 2.20 to $2.07 \mathrm{Ga}$ and are affected by amphibolite to granulite facies metamorphism dated at $1950 \pm 15 \mathrm{Ma}$. Whole rock Sm-Nd isotopic data on various gneisses yield Archean depleted mantle model ages $\left(\mathrm{T}_{\mathrm{DM}}\right)$ ranging from 3.01 to $2.64 \mathrm{Ga}$ (see Norconsult Consortium [2007a] for a detailed description of the complex and its lithological and metamorphic characteristics). Paleoproterozoic crust with Archean Sm-Nd isotopic signature is described in the Usagaran, Ubendian, and Northern Irumide belts in Tanzania, Malawi and Zambia [e.g., Lenoir et al., 1994; Ring et al., 1997; Vrána et al., 2004; De Waele et al., 2006]. Available geochronological data therefore link the Ponta Messuli Complex to these belts. The Usagaran, Ubendian and Northern Irumide belts are situated along the margin of the Archaean Congo-Tanzania craton. This suggests that the Ponta Messuli Complex is also part of this margin and can consequently be regarded as a part of the Congo-Tanzania cratonic foreland to the Pan-African East African Orogen. Its direct structural relationships to the CDNC other than the Txitonga Group are unfortunately obliterated by the NE-SW trending, Permo-Triassic Maniamba Graben, infilled by Karoo Supergroup sediments (Figure 18).

\subsection{Cabo Delgado Nappe Complex}

[52] To the SE of the Ponta Messuli Complex, the CDNC comprises a series of thrust-bounded imbricates that, prior to their subsequent folding, dipped gently to the SSE-SE. Our model for northern Mozambique differs from other studies in that the reconstructed regional nappe transport direction (at least to the north of the Lurio Belt, where most of our observations were made) is to the NW and not to the SE [e.g., Grantham et al., 2008]. Dominantly top-to-theNW and -WNW transport is reported also from the mylonitic base of other granulite facies nappe complexes in the EAO [e.g., Muhongo, 1994; Fritz et al., 2005]. Possible structural correlatives to the CDNC may thus be found, for example, farther to the north, in Tanzania and Kenya, where a series of Pan-African granulite gneiss terranes, the Eastern Granulites, is reported. These rest discordantly along thrust contacts over older basements (e.g., Pare Mountains [Bagnall, 1963; Muhongo and Lenoir, 1994; Appel et al., 1998; Möller et al., 2000]; Usambara Mountains [Möller et al., 2000]; Wami River [Maboko et al., 1985]; Uluguru Mountains [Muhongo, 1994; Appel et al., 1998; Muhongo and Lenoir, 1994]; Furua [Coolen et al., 1982; Fritz et al., 2005]). In addition, we tentatively suggest that the Mugeba and Monapo complexes, located south of the Lurio Belt (Figure 18), can also be interpreted as erosional remnants of the once much more extensive CDNC. Recent mapping and investigations [Sacchi et al., 2000; Norconsult Consortium, 2007a; Macey et al., 2007] confirmed not only that these share significant similarities with other complexes within the CDNC in northern Mozambique but also that they are juxtaposed tectonically against the underlying Nampula Complex along very distinctive, shallow dipping mylonitic 
Table 2. LA-ICPMS U-Pb Data for Monazites From Banded Gneiss, Sample 33310-BB060, Monazite

\begin{tabular}{|c|c|c|c|c|c|c|c|c|c|c|c|c|c|}
\hline $\mathrm{ID}^{\mathrm{a}}$ & $\begin{array}{l}{ }^{206} \mathrm{~Pb} / \\
{ }^{204} \mathrm{~Pb}^{\mathrm{b}}\end{array}$ & $\begin{array}{l}{ }^{207} \mathrm{~Pb} / \\
{ }^{206} \mathrm{~Pb}^{\mathrm{c}}\end{array}$ & $\begin{array}{l}1 \sigma \\
(\%)\end{array}$ & $\begin{array}{l}{ }^{207} \mathrm{~Pb} / \\
{ }^{235} \mathrm{U}^{\mathrm{c}}\end{array}$ & $\begin{array}{l}1 \sigma \\
(\%)\end{array}$ & $\begin{array}{l}{ }^{206} \mathrm{~Pb} / \\
{ }^{238} \mathrm{U}^{\mathrm{c}}\end{array}$ & $\begin{array}{l}1 \sigma \\
(\%)\end{array}$ & $\mathrm{Co}^{\mathrm{d}}$ & $\begin{array}{c}{ }^{206} \mathrm{~Pb} /{ }^{238} \mathrm{U}^{\mathrm{e}} \\
(\mathrm{Ma})\end{array}$ & $\begin{array}{l}1 \sigma \\
(\%)\end{array}$ & $\begin{array}{c}{ }^{207} \mathrm{~Pb} /{ }^{206} \mathrm{~Pb}^{\mathrm{e}} \\
(\mathrm{Ma})\end{array}$ & $\begin{array}{l}1 \sigma \\
(\%)\end{array}$ & $\begin{array}{l}\mathrm{Di}^{\mathrm{f}} \\
(\%)\end{array}$ \\
\hline 31 & 866 & 0.05614 & 6.9 & 0.6312 & 7.0 & 0.08 & 1.3 & 0.19 & 505 & 6 & 458 & 153 & -10 \\
\hline 35 & 1215 & 0.05905 & 4.9 & 0.6788 & 5.0 & 0.08 & 1.2 & 0.24 & 516 & 6 & 569 & 107 & 9.2 \\
\hline 32 & 3118 & 0.05785 & 1.5 & 0.6661 & 1.8 & 0.08 & 1.1 & 0.57 & 517 & 5 & 524 & 33 & 1.3 \\
\hline 02 & 11379 & 0.05879 & 0.7 & 0.6863 & 1.2 & 0.08 & 1.0 & 0.81 & 524 & 5 & 559 & 16 & 6.3 \\
\hline 37 & 3163 & 0.05849 & 1.8 & 0.6843 & 2.2 & 0.08 & 1.2 & 0.55 & 525 & 6 & 548 & 40 & 4.3 \\
\hline 06 & 4479 & 0.05686 & 1.4 & 0.6664 & 1.7 & 0.09 & 1.1 & 0.61 & 526 & 5 & 486 & 31 & -8.2 \\
\hline 08 & 7349 & 0.05838 & 0.8 & 0.6852 & 1.3 & 0.09 & 1.0 & 0.80 & 527 & 5 & 544 & 17 & 3.2 \\
\hline 03 & 6555 & 0.05815 & 0.9 & 0.6831 & 1.4 & 0.09 & 1.0 & 0.75 & 527 & 5 & 535 & 20 & 1.5 \\
\hline 34 & 5478 & 0.05840 & 1.3 & 0.6887 & 1.6 & 0.09 & 0.9 & 0.58 & 529 & 5 & 545 & 28 & 2.9 \\
\hline 41 & 4354 & 0.05797 & 1.6 & 0.6849 & 2.1 & 0.09 & 1.4 & 0.67 & 530 & 7 & 529 & 35 & -0.2 \\
\hline 43 & 1533 & 0.05633 & 3.6 & 0.6679 & 3.9 & 0.09 & 1.5 & 0.37 & 532 & 7 & 465 & 80 & -14 \\
\hline 14 & 7089 & 0.05764 & 0.7 & 0.6844 & 1.3 & 0.09 & 1.1 & 0.83 & 532 & 5 & 516 & 15 & -3.1 \\
\hline 01 & 6664 & 0.05773 & 0.7 & 0.6927 & 1.2 & 0.09 & 1.0 & 0.83 & 538 & 5 & 520 & 15 & -3.5 \\
\hline 39 & 5655 & 0.05864 & 1.3 & 0.7066 & 1.8 & 0.09 & 1.1 & 0.65 & 540 & 6 & 554 & 29 & 2.5 \\
\hline 09 & 11601 & 0.05856 & 0.6 & 0.7083 & 1.2 & 0.09 & 1.1 & 0.88 & 542 & 6 & 551 & 13 & 1.6 \\
\hline 11 & 5711 & 0.05848 & 0.7 & 0.7138 & 1.4 & 0.09 & 1.2 & 0.87 & 547 & 6 & 548 & 15 & 0.2 \\
\hline 13 & 6002 & 0.05746 & 0.8 & 0.7054 & 1.3 & 0.09 & 1.1 & 0.82 & 550 & 6 & 509 & 17 & -8.0 \\
\hline 07 & 5613 & 0.05793 & 0.9 & 0.7119 & 1.5 & 0.09 & 1.1 & 0.78 & 550 & 6 & 527 & 20 & -4.4 \\
\hline 33 & 6074 & 0.05773 & 1.3 & 0.7108 & 2.0 & 0.09 & 1.5 & 0.75 & 551 & 8 & 520 & 28 & -6.1 \\
\hline 18 & 6364 & 0.05794 & 0.9 & 0.7170 & 1.4 & 0.09 & 1.1 & 0.78 & 554 & 6 & 528 & 19 & -5.0 \\
\hline 20 & 21128 & 0.05858 & 0.4 & 0.7318 & 1.2 & 0.09 & 1.1 & 0.95 & 559 & 6 & 551 & 8 & -1.4 \\
\hline 16 & 11405 & 0.05839 & 0.6 & 0.7344 & 1.3 & 0.09 & 1.1 & 0.87 & 563 & 6 & 544 & 14 & -3.4 \\
\hline 44 & 5593 & 0.05896 & 1.1 & 0.7453 & 1.7 & 0.09 & 1.2 & 0.73 & 565 & 7 & 566 & 25 & 0.0 \\
\hline 42 & 6947 & 0.05781 & 1.2 & 0.7340 & 2.0 & 0.09 & 1.5 & 0.78 & 568 & 8 & 523 & 27 & -8.6 \\
\hline 45 & 6303 & 0.05941 & 1.2 & 0.7560 & 1.9 & 0.09 & 1.4 & 0.76 & 569 & 8 & 582 & 26 & 2.3 \\
\hline 36 & 3270 & 0.05893 & 2.0 & 0.7504 & 2.4 & 0.09 & 1.3 & 0.53 & 569 & 7 & 565 & 44 & -0.8 \\
\hline 38 & 4832 & 0.05817 & 1.3 & 0.7411 & 2.0 & 0.09 & 1.5 & 0.77 & 570 & 8 & 536 & 28 & -6.3 \\
\hline 19 & 7643 & 0.05885 & 0.8 & 0.7579 & 2.0 & 0.09 & 1.8 & 0.92 & 576 & 10 & 561 & 17 & -2.5 \\
\hline 40 & 4327 & 0.05673 & 1.4 & 0.7348 & 2.0 & 0.09 & 1.4 & 0.71 & 579 & 8 & 481 & 32 & -20 \\
\hline 12 & 9414 & 0.05862 & 0.5 & 0.7634 & 1.5 & 0.09 & 1.4 & 0.93 & 582 & 8 & 553 & 12 & -5.2 \\
\hline 10 & 11881 & 0.05831 & 0.6 & 0.7653 & 1.5 & 0.1 & 1.4 & 0.92 & 586 & 8 & 541 & 13 & -8.3 \\
\hline 21 & 19941 & 0.05826 & 0.6 & 0.7672 & 1.7 & 0.1 & 1.6 & 0.93 & 588 & 9 & 540 & 14 & -8.9 \\
\hline 15 & 9706 & 0.05798 & 0.6 & 0.7683 & 1.3 & 0.1 & 1.2 & 0.89 & 592 & 7 & 529 & 13 & -12 \\
\hline 17 & 9408 & 0.05797 & 0.7 & 0.8046 & 1.6 & 0.1 & 1.4 & 0.90 & 618 & 8 & 529 & 15 & -17 \\
\hline
\end{tabular}

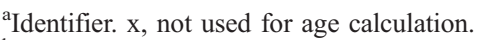

${ }^{\mathrm{b}}$ Measured ratio.

${ }^{\mathrm{c}}$ Ratio corrected for common $\mathrm{Pb}$.

${ }^{\mathrm{d}}$ Correlation of errors.

${ }^{\mathrm{e}}$ Age corrected for common $\mathrm{Pb}$.

${ }^{\mathrm{f}}$ Discordance of the analysis: $100-\left(100 \times\left({ }^{206} \mathrm{~Pb} /{ }^{238} \mathrm{U}\right)\right.$ age $/\left({ }^{207} \mathrm{~Pb} /{ }^{206} \mathrm{~Pb}\right)$ age $)$.

sequences. The complete kinematic characterization of these mylonitic thrust contacts unfortunately remains undetermined to date.

[53] Apart from the similar structural setting, there are other striking similarities between all the granulite terranes making up the CDNC, such as the occurrence of abundant metasedimentary sequences, including marble and graphite schist, the occurrence of metavolcanic rocks associated with the metasediments, a widespread Neoproterozoic age signature and evidence for pre- to early Pan-African granulitefacies metamorphism. All these features suggest that these terranes are genetically linked and that they once belonged to the same continental-scale tectonic unit, although further supporting evidence needs to be gathered, for example, additional metamorphic ages in the various terranes and detailed PT studies within individual nappes and across their tectonic contacts. Indeed, it should be borne in mind that the tectonic imbricates that are presently juxtaposed in a structurally coherent thrust and fold belt may originally have been at very different crustal levels and may have under- gone separate and complex PT evolutions, possibly within different continental or arc blocks. As an example, the CDNC in northern Mozambique preserves two separate granulite facies metamorphic phases at $735 \pm 4 \mathrm{Ma}$ (documented within the Xixano Complex) and at $631 \pm 6$ to $607 \pm$ $11 \mathrm{Ma}$ (within the M'Sawize, Xixano and Meluco complexes [Bingen et al., 2007]). As suggested by Muhongo [1994], these mylonite-bounded high-grade metamorphic rocks can be regarded as "large, discontinuous discrete thrust sheets or nappes originating from deeper structural levels and whose emplacement (and detachment) and subsequent extensive erosion has exposed the deep roots, or a part of the internal zone of a collisional orogen."

[54] We propose here that the newly defined CDNC can unify all of these granulite complexes in a single fold and thrust belt model, until more detailed work allows a more rigorous geodynamic reconstruction of the accretion process that, at different times, led to the eventual juxtaposition of the observed nappe stack. The Neoproterozoic magmatic rocks and the $\sim 735$ to $615 \mathrm{Ma}$ granulite facies metamor- 


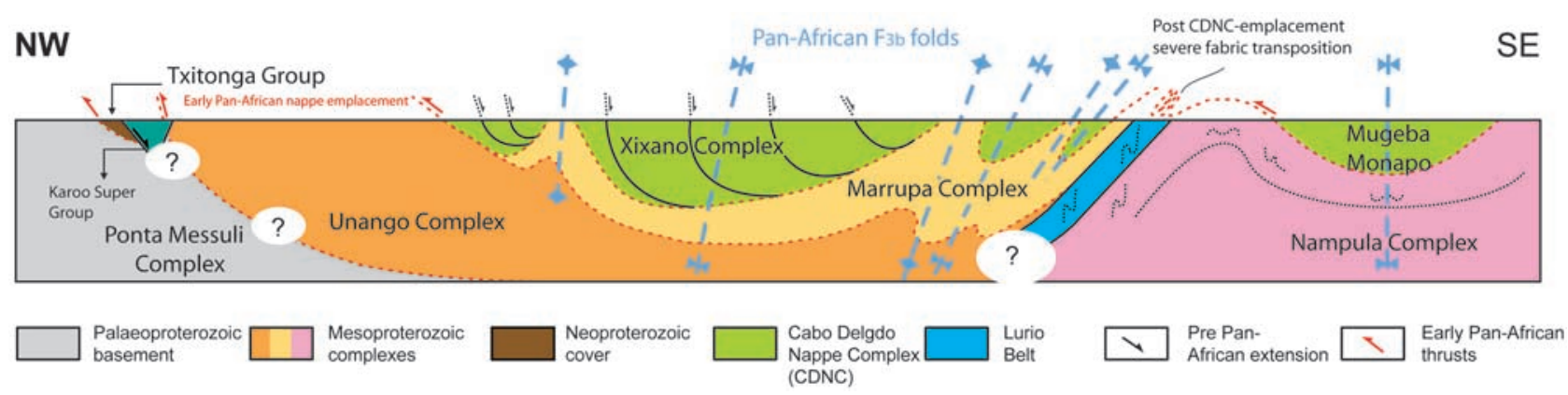

Figure 18. Sketch NW-SE trending cross section across NE Mozambique. The profile illustrates firstorder structural relationships between the main constituents of the newly established tectonostratigraphy and of the present-day regional tectonic framework. The pre-Pan-African normal faults drawn in black within the CDNC are not dealt with in detail in this paper. Readers are referred to Norconsult Consortium [2007a] for details on their geometric and kinematic characteristics. Note the severe fabric transposition of the CDNC within the Lurio Belt, with overtightened and laterally segmented $\mathrm{F}_{3 \mathrm{a}}$ folds with axial planes forming the main planar fabric of the belt. The belt is also folded by later, but coaxial, $F_{3 b}$ folds, and the second-order folds sketched (thin dashed lines) are parasitic to a large $\mathrm{F}_{3 \mathrm{~b}}$ antiform, the core of which exhumes part of the Nampula Complex, characterized by the youngest dated metamorphism in the area.

phism observed in CDNC are not recorded in the underlying Mesoproterozoic felsic crust. This implies that the nappes are far-traveled and originated "outboard" of the Mesoproterozoic felsic crustal blocks currently exposed in NE Mozambique. Consequently, we suggest that the CDNC in NE Mozambique, south and north of the Lurio Belt, and the Eastern Granulites farther north are remnants of Neoproterozoic volcanic arcs and microcontinents formed "outboard" of the Mesoproterozoic continent [e.g., Jacobs and Thomas, 2002]. These were possibly located at the margin, or in the middle of the Mozambique Ocean, before closing of this ocean during the Pan-African orogeny, which involved indigenous and accreted lithologies, transported with topto-the-NW kinematics onto the Congo-Tanzania margin between $596 \pm 11 \mathrm{Ma}$ (youngest pluton in the nappes) and circa $550 \mathrm{Ma}$ (metamorphism age in underlying Marrupa Complex [Norconsult Consortium, 2007a]). The roots of the CDNC must lie, therefore, somewhere to the south of present-day Mozambique, arguably in East Antarctica.

[55] It should be noted that preservation of granulite facies rocks within individual imbricates of the CDNC requires a phase of exhumation postdating their formation but predating nappe imbrication. No obvious convincing structural evidence was found to allow for the characterization of the geometry and kinematics of such an exhumation phase. Scattered, extensional ductile shear zones accommodating top-to-the-SE extension within the Marrupa Complex have been observed [Norconsult Consortium, 2007a] but are not discussed in this paper. We only mention here that their relatively early origin in the regional tectonic evolution is inferred from the fact that these extensional fabrics are affected by the NW directed thrust-related deformation phase, shown in Figure 18, that folded them in open $F_{3 b}$ folds around subhorizontal axes trending NE-SW. This is not the case for the younger, $\mathrm{D}_{5}$ postimbrication extensional features described in section 4.5, which cut across nappe contacts, are not affected by folding and accommodated final thinning of the East African Orogen.
[56] Within this nappe stack framework there clearly are points of detail open to debate. As shown in Figure 18, for example, we lack constraints on the lateral geometric and temporal relationships between the Nampula and the Unango complexes. From a geochemical point of view, the two complexes are quite similar [Norconsult Consortium, 2007a]. However, they are presently juxtaposed along a very poorly exposed tectonic contact, the nature of which it has proven difficult to unravel (Figure 1c). Whereas prePan-African intrusive ages within the Nampula Complex are generally older than within the Unango (1100 Ma versus $1000 \mathrm{Ma}$ or younger [Norconsult Consortium, 2007a]), possibly indicating different evolutions in pre-Pan-African times, Pan-African metamorphic ages are broadly coeval, implying juxtaposition by Pan-African times and a common later thermotectonic history. Whether these two terranes were already juxtaposed during the Mesoproterozoic orogeny (i.e., during the formation of Rodinia) is another unanswered question.

\subsection{Lurio Belt}

[57] Having discussed the origin and the characteristics of the CDNC, it is now important to discuss the Lurio Belt and its significance in the regional picture. Figure 19 suggests a possible scenario for the formation of the Ocua Complex in the core of the Lurio Belt. The Ocua Complex contains high-P granulite boudins dated at $557 \pm 16 \mathrm{Ma}$, evidence for deformation at least until $532 \pm 13 \mathrm{Ma}$ and abundant $612 \pm$ 6 to $504 \pm 11 \mathrm{Ma}$ felsic plutons [Norconsult Consortium, 2007a]. It is thus characterized by a range of dates that are significantly younger than that obtained for the CDNC. The Ocua Complex is envisaged here as having formed during the CDNC nappe stacking episode at the base of the thick translating nappe stack (or part of it), possibly acting as basal detachment immediately above the overridden Mesoproterozoic parautochtonous basement. Because of the later pervasive overprint, we have no direct information as to 


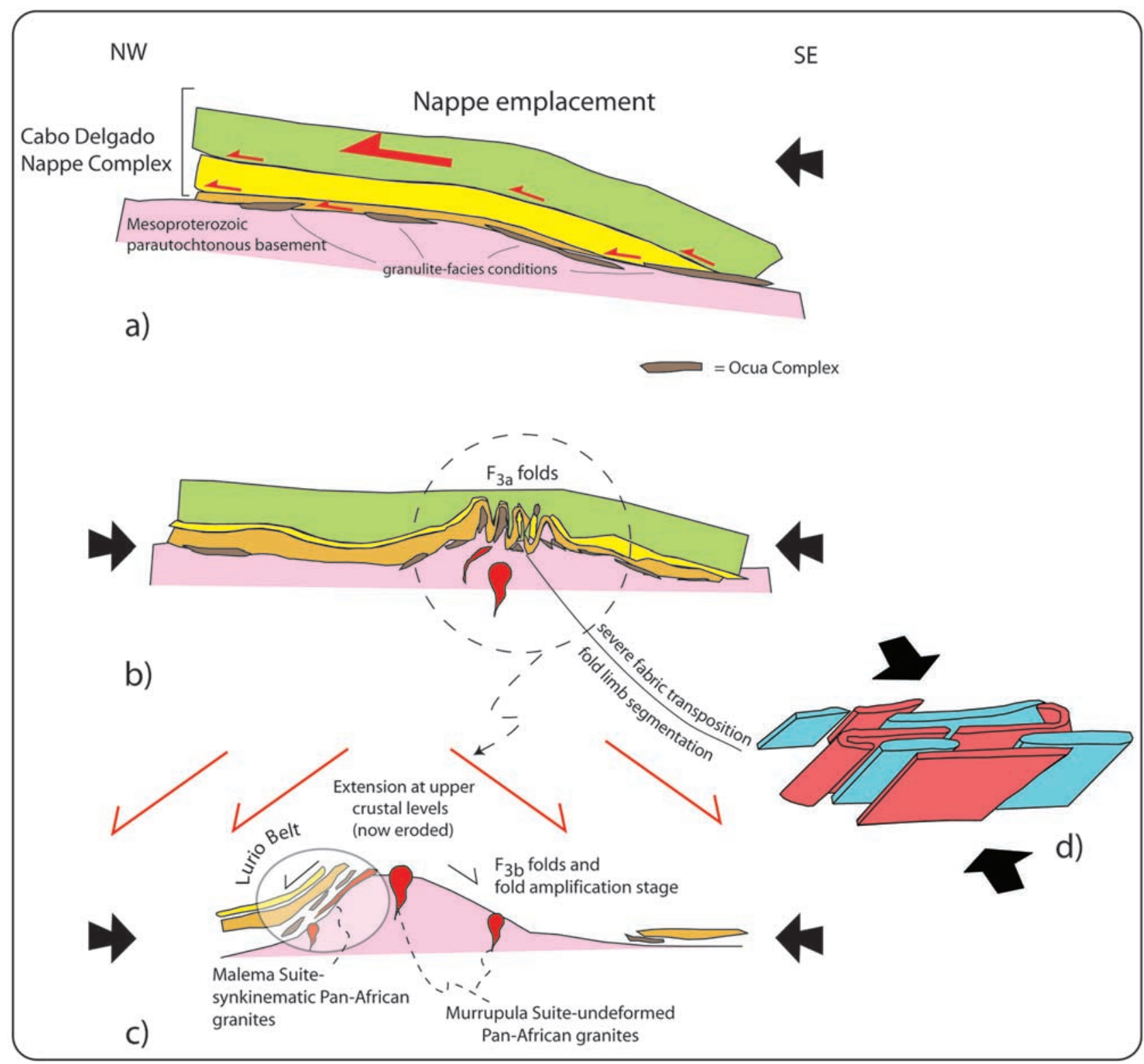

Figure 19. Possible scenario for the development of the Ocua Complex, now exposed within the Lurio Belt. See the text for details.

whether the Ocua Complex was ever an independent coherent lithotectonic unit prior to this event, or if its present mélange-like character resulted entirely from the shearing and transposition at depth of components from several nappes. It is reasonable to assume, though, that the observed granulite facies metamorphic overprint within the Ocua Complex started during this stage, i.e., during the crustal-thickening episode driven by converging plate movements. $\mathrm{D}_{2}$ structures reported from the western Lurio Belt were probably formed during this event and possibly reflect regional transport and deformation at this time.

[58] During subsequent folding, tight to isoclinal $\mathrm{F}_{3 \mathrm{a}}$ folds developed, leading to severe transposition and wholesale segmentation of the Ocua Complex lithologies. It is not clear why such a significant strain accommodation occurred predominantly within the Lurio Belt, but the presence of an older, inherited deep-seated structural discontinuity, possible of Mesoproterozoic age, is a likely explanation. Flatramp-flat-type geometries along the thrust contact may also have played an important role in localizing subsequent strain. Flattening and limb disruption of $\mathrm{F}_{3 \mathrm{a}}$ folds (e.g., Figures $19 \mathrm{~b}$ and 19d) occurred under granulite facies conditions and led to the development of the tectonic mélange seen today, with contributions to the final lithological assembly from several nappes (Xixano, Marrupa, probably Nampula). At this stage (circa $500 \mathrm{Ma}$ ), granitoid plutons of the Murrupula and Malema suites were intruded [Norconsult Consortium, 2007a]. Some of these plutons were involved in 
the flattening domains and were deformed (part of the Malema Suite), whereas others remained essentially undeformed (Murrupula Suite; Figure 19c).

[59] Continued shortening and folding led to the formation of $F_{3 b}$ folds after the lock-up stage of $F_{3 a}$ folding was reached (see Figure 19c). Fold amplification and growth at deeper crustal levels created a site of enhanced exhumation in the core of such folds. This model is supported by metamorphic ages from the NW part of the Nampula Complex, which are among the youngest obtained during this study (490-500 Ma [Norconsult Consortium, 2007a]). Thus, Figure 19c shows the northernmost part of the Nampula Complex occurring within the core of a largescale $F_{3 b}$ antiform, whose geometry may have enhanced preferential relatively late exhumation in its hinge zone, possibly also due to a component of transtension and oblique slip along its limbs, triggered by the oblique flexural folding mechanisms noted above.

[60] In conclusion, the Lurio Belt is interpreted here as an integral part of the $\mathrm{F}_{3 \mathrm{a}}$ and $\mathrm{F}_{3 \mathrm{~b}}$ fold framework; we believe that it represents an exhumed site of preferential shortening and pure shear accommodation at the northern limb of a gently south verging antiform developed in the Nampula Complex. Our fieldwork and investigations exclude significant, regional along-strike displacement associated with the belt, at least as far as the preserved structures can demonstrate. Similarly, no evidence of thrusting was found in the belt. According to these results, there is no proper "foreland" or "hinterland" to the Lurio Belt, which is not a classic thrust belt, but instead is a crustal-scale flattening zone, which can be viewed as a "megazone" of axial plane cleavage. Engvik et al. [2007] have recently illustrated metamorphic decompressional features in the HP Ocua granulites, indicating a rapid exhumation along a clockwise PT path under almost isothermal conditions, probably resulting from overthickening of the crust during collision.

[61] Taken as a whole, the field structural evidence presented in this paper does not, therefore, support a straightforward interpretation of the Lurio Belt as a prominent suture zone [cf. Grantham et al., 2008]. First, it is only belt-like in its eastern part and the structures become diffuse and much less readily identifiable to the SW. Moreover, the observation that the original extent of the CDNC nappes was both north and south of the belt further weakens models, which view the Lurio Belt as a fundamental PanAfrican discontinuity separating totally different crustal domains. On the other hand, it has been shown that the Lurio Belt is a significant structure that accommodated multiple deformation events right up to the latest stages of the waning Pan-African deformation to such an extent that no evidence is preserved of any earlier history, including the possible existence of a Pan-African and/or older suture zone.

\subsection{Crustal Extension}

[62] Irrespective of the original significance of the Lurio Belt, crustal thickening at the end of the CDNC-forming process must have been sufficient to generate granitic melts, leading to major gravitational instabilities. These would have resulted in crustal collapse and extension at the orogen scale, a process that is now commonly recognized during the terminal phase of collisional orogeny [e.g., Dewey, 1988; Houseman and England, 1993; Burg et al., 1994; Fossen, 2000]. Pan-African granitic plutons, dated between $548 \pm 13$ and $495 \pm 13 \mathrm{Ma}$ (Murrupula, Malema, and Niassa suites [Norconsult Consortium, 2007a]), were intruded into the Mesoproterozoic rocks of the Nampula, Unango, and Marrupa complexes, although they are significantly most voluminous in the Nampula Complex, to the south of the Lurio Belt. Within the Lurio Belt itself, the Malema Suite [Norconsult Consortium, 2007a] includes numbers of both strongly foliated, synkinematic sheet-like intrusions and postkinematic subcircular plutons. In general, both the relative and absolute timing of crustal thickening during the NW directed nappe stacking event and subsequent gravitational collapse of the Pan-African orogen, crustal thinning and intrusion of Pan-African granitic magmas, suggest a close relationship between tectonics and magmatism [e.g., Jacobs et al., 2008]. New geochronological data presented in this paper from an extensional melt and an extensional mylonite in the Ocua Complex confirm a date of extension in the eastern Lurio Belt at $\sim 535 \mathrm{Ma}$.

[63] The EAO is presently deeply exhumed, and tectonic denudation has certainly played an important role in the removal of its now missing upper crustal section. Despite the importance of the late extensional episode, however, a complete understanding of its precise nature and full extent over the orogen is still very incomplete, due to the generally poor field structural documentation and lack of direct geochronological constraints. Nevertheless, discrete extensional and mylonitic shear zones cutting earlier collisionalcompressional stages of Pan-African tectonic evolution are documented in a number of locations. In Madagascar, for example, the timing of both collision and subsequent extension of the orogen are remarkably similar to that documented here for NE Mozambique (with extensional tectonics between 540 and $490 \mathrm{Ma}$ ) [e.g., Nédélec et al., 1995; Tucker et al., 1999; Kröner et al., 1999; Collins et al., 2000; de Wit et al., 2001]. In addition, Nédélec et al. [1995] contended that crustal extension is a necessary prerequisite for the development of the synkinematic to postkinematic plutonism widespread in both Madagascar and East Africa. Other lines of evidence for late extension are provided for by dilation and intrusion of NE-SW and NNW-SSE trending dike swarms at circa $493 \mathrm{Ma}$ in the far north of the orogenic belt in Egypt [Abdel-Rahman, 1995] and the Cambrian evaporites and clastic (molasse?) sequences, which have been reported from large areas of the EAO. The timing of extension may be diachronous over the orogen. For example, Beyth et al. [2003] and Blasband et al. [2000] described large-scale gravitational collapse between circa 640-545 Ma in the Pan-African of Eritrea, slightly earlier than apparent in NE Mozambique.

[64] On a still broader scale in Gondwana, similar sequences of events have also been suggested from extensive areas in Antarctica, southern India, Sri Lanka and Brazil [e.g., Unrug, 1992; Pimental et al., 1999; Jacobs et al., 2003]. In Dronning Maud Land, Antarctica, which may have lain immediately to the south of Mozambique in 
Gondwana, Jacobs et al. [2003], Engvik and Elvevold [2004], and Jacobs et al. [2008] have reported widespread extensional deformation that postdated the main Pan-African collision, on a comparable timescale.

[65] In summary, it is probable that these structures are all part of the same widespread extensional tectonism; our data from northern Mozambique conform to this regional model.

[66] As to the driving forces of such an important extensional phase, orogen collapse seems the most likely first-order mechanism within the study area, given the size and the thickness of the proposed CDNC fold and thrust belt. As to how this actually occurred, a number of geodynamic mechanisms have been proposed. Jacobs and Thomas [2004] framed the extensional phase of the southern domain of the EAO in a theoretical scheme of southward escape tectonics. More recently, Jacobs et al. [2008] analyzed the distribution, age and characteristics of the voluminous Pan-African granites in Dronning Maud Land and NE Mozambique south of the Lurio Belt, to demonstrate that extension and granitoid intrusions were synchronous and an expression of large-scale orogenic collapse. They speculated that the magmatic event might have been the result of a process of delamination of the orogenic root of the East African Orogen, triggering asthenosphere uprise and melt generation along, and mainly south of, the Lurio Belt. In this model, the Lurio Belt would represent an accommodation zone between two thermomechanically different parts of the orogen and not a suture zone. On a cautionary note, de Wit et al. [2001] stressed the importance of far-field extensional plate boundary stresses that developed contemporaneously with the late extension throughout Gondwana, suggesting that destabilization of the PanAfrican belts might have been driven by more fundamental plate reorganization mechanisms in the heart and along the rims of the supercontinent.

\section{Implications of the Study for Gondwana Reconstructions}

[67] The complex, multiphase tectonic history that has been deciphered from NE Mozambique confirms the polycyclic nature of the EAO. There is by now little doubt that the assembly of Gondwana was far from being a simple process involving one single collisional event between East and West Gondwana and the closure of a very large intervening Pacific-type oceanic basin. Consequently, the original view that the Mozambique Belt in the sense of Holmes [1951] represents a long, linear collision event has become untenable [e.g., Stern, 1994]. Furthermore, Johnson et al. [2005] for example, suggest, on the basis of the spatial distribution of metamorphic ages and the differences in timing of peak metamorphism across southern Africa, that Gondwana amalgamation involved a diachronous, longlived series of collisional events between several cratonic fragments. Also, any plate reconstruction model of that event has to consider not only the closure of the $\mathrm{N}-\mathrm{S}$ trending Mozambique Ocean, but also the closure of the Zambesi-Adamastor oceans and the subsequent DamaraLufillian-Zambezi Orogen (see Figure 1a). Thus, the roughly
E-W trending Pan-African system of central southern Africa, characterized by collision-induced metamorphism at circa $550-520 \mathrm{Ma}$, has to be fully integrated in plate tectonic reconstructions of the orogenic event.

[68] One of the major difficulties in attempting to unravel the evolution of the amalgamation process is that the collision of the many blocks involved is likely to have lasted at least $100 \mathrm{Ma}$ (see the comprehensive reviews by Möller et al. [2000] and Meert [2003]). As discussed above, the metamorphic age signature of the individual nappes within the CDNC differs significantly from that of the overridden Mesoproterozoic basement and, more importantly, from the younger ages obtained from within the Lurio Belt (granulite facies metamorphism at $557 \pm 16 \mathrm{Ma}$ [Engvik et al., 2007]). The results of our study and of Norconsult Consortium [2007a] confirm this long time interval and even expand it by reporting granulite metamorphic ages of circa $730 \mathrm{Ma}$ from the Xixano nappe. This extremely prolonged time span and its tectonic implications have already been recognized, such that Meert [2003] introduced the concept of a "Kunga Orogeny" as a later (?) orogenic phase, separate from the EAO. However, a detailed structural framework was never provided to explain the early accretion phase and differences in ages and cooling histories among the different granulite terranes were thus used to merely suggest the existence of "important but hidden faults" [Möller et al., 2000].

[69] Our contribution has elucidated, for the first time, the geometry and kinematics of the early accretion event on a large-scale by proposing a single thrust and fold belt that affected much of the southern part of the EAO. We believe that the detailed description of the architecture of the CDNC represents an important step toward a better understanding of the amalgamation process of Gondwana. Irrespective of the significance attributed to the peak metamorphism ages within the $\mathrm{CDNC}$ individual imbricates (i.e., granulite metamorphism being the result of continent-continent collision or of underplating and intrusion of magmas into the crust; see Appel et al. [1998] and Möller et al. [2000] versus Sommer et al. [2003]), the size and original regional extent of the thrust and fold belt are such that it is indeed feasible to support an early collision or, more probably, series of collisions, between several slivers of continental crust and/ or volcanic arcs between 800 and 650 Ma during the closure of the northern part of the Mozambique Ocean, with an overall top-to-the-NW transport direction.

[70] The granulite facies metamorphism in the Lurio Belt, dated at $557 \pm 16 \mathrm{Ma}$, is similar to the circa $550-520 \mathrm{Ma}$ age of collisional metamorphism in the Zambesi Belt and to the 540-510 Ma range proposed for the Damara Belt [Jung et al., 2001; Jung and Mezger, 2003]. Structures leading to extreme flattening and dismembering of the Ocua Complex granulites within the Lurio Belt were formed in response to a prolonged, roughly NW-SE oriented shortening phase. This shortening direction is essentially coaxial with the compression direction that caused imbrication and folding within the CDNC, possibly suggesting that a single, extremely long-lived contractional episode was operative over the whole of southern Gondwana at that time. In any case, 
more detailed work is needed to ascertain if the Lurio Belt preserves concealed evidence of being a major Pan-African suture zone, representing the continuation of the DamaraLufillian-Zambezi orogenic system as mooted, for example, by Grantham et al. [2008]. In the absence of this compelling evidence, however, we interpret the younger timing of metamorphism and deformation preserved within the Lurio Belt as reflecting second-order, late adjustments within an already assembled Gondwana, not necessarily reflecting the closure of an oceanic trough. It seems very plausible that these later adjustments occurred along an inherited, probably Mesoproterozoic, crustal discontinuity.

\section{Conclusions}

[71] The integrated approach to the geology of northern Mozambique adopted here, and made possible by the recently completed regional mapping program [Norconsult Consortium, 2007a], has led to a number of major conclusions regarding the tectonic evolution of this sector of the East African Orogen in the sense of Stern [1994]. The tectonostratigraphy of NE Mozambique can be subdivided into five megatectonic units on the basis of lithology, structure and geochronology: unit 1, the Paleoproterozoic Ponta Messuli Complex in the extreme NW corner of NE Mozambique, which represents the local NW foreland to the EAO; unit 2, a collage of Mesoproterozoic metamorphic complexes which forms the basement to unit 3, a stack of Neoproterozoic, NW directed thrust nappes named here the "Cabo Delgado Nappe Complex" (CDNC); unit 4, localized Neoproterozoic metasedimentary basins; and unit 5, two exotic Neoproterozoic granulite mélange complexes.

[72] The Neoproterozoic (Pan-African) structural evolution of this architecture can be summarized as follows:

[73] 1. Unit 3, i.e., the CDNC, is interpreted as a major, continental-scale Pan-African fold and thrust belt. Nappe emplacement occurred with an overall top-to-the-NW transport direction and led to the juxtaposition of "far-traveled" crustal imbricates containing some Neoproterozoic magmatic suites and showing granulite facies metamorphism that are absent in the overridden Mesoproterozoic basement. The CDNC must have be rooted somewhere in East Antarctica, which lay to the south of Mozambique in Gondwana. It is unclear if the collage of Mesoproterozoic complexes which forms most of the basement to the CDNC (megatectonic unit 2) was assembled during an early phase of this imbrication process or if the complexes had already been juxtaposed during the Mesoproterozoic orogenesis at $\sim 1100 \mathrm{Ma}$. It is proposed that the CDNC in NE Mozambique and the Eastern Granulites farther north are remnants of Neoproterozoic volcanic arcs and microcontinents formed "outboard" of the Mesoproterozoic continent. A possible reconstruction locates them at the margin, or in the middle of the Mozambique Ocean prior to its subsequent closure during the Pan-African orogeny, which involved the transport of indigenous and accreted lithologies, onto the CongoTanzania margin after $596 \pm 11 \mathrm{Ma}$;

[74] 2. Field data, integrated with the interpretation of a new airborne geophysical survey, show that the nappes were folded by regional-scale NE-SW trending folds that formed in response to the same shortening episode that caused nappe imbrication;

[75] 3. We interpret the Lurio Belt, a prominent structural feature of northern Mozambique and a key element, often as a suture zone, in many Gondwana reconstructions, as a structure generated by continuous shortening and folding of the CDNC during later stages of the progressive shortening event of 1 and 2. No structural evidence was obtained to confirm that the Lurio Belt accommodated regionally important along-strike shear or thrusting. Instead, the Lurio Belt appears to be a repeatedly reactivated shear zone with an intense pure shear deformation history. It is cored by strongly attenuated lenses of a granulitic tectonic mélange, the Ocua Complex (megatectonic unit 5) and intruded by late Pan-African granitoids of the Malema Suite.

[76] 4. Field evidence is presented for a top-to-the-NW and $-\mathrm{SE}$ extensional phase that postdates the compressive phases of 1 and 2. New geochronological data show that extension initiation can be dated at circa $535 \mathrm{Ma}$ in the eastern Lurio Belt and is believed to be the result of a major episode of orogenic collapse of the EAO, initiated by the gravitational instabilities resulting from crustal thickening during the shortening phase.

[77] Finally, it is important to stress the utility of an integrated approach to the study of complex tectonic histories, whereby well-coordinated multidisciplinary efforts can lead to the establishment of an internally consistent, regional tectonic model. The area investigated in northern Mozambique has provided a unique possibility to study the full structural and tectonic timescale throughout the building up and the tearing down of part of this huge Pan-African orogen.

[78] Acknowledgments. This project was carried out within contracts funded by the World Bank and the Nordic Development Fund and implemented by a team from the Geological Survey of Norway, the British Geological Survey, the National Directorate of Geology of Mozambique, and the University Eduardo Mondlane, Maputo, Mozambique, under the management of Rognvald Boyd, Geological Survey of Norway. R. J. Thomas publishes with the permission of the Executive Director of BGS. The results presented in this paper were made possible only thanks to the involvement and cooperation of all participants. Every geologist who took part to the program has played a pivotal role in the generation of the ideas presented here, and our deepest gratitude goes to them all. Harald Fritz and Geoff Grantham provided constructive reviews and are thanked for raising several interesting points.

\section{References}

Abdel-Rahman, A. F. M. (1995), Tectonic-magmatic stages of shield evolution: The Pan-African belt in northeastern Egypt, Tectonophysics, 242, 223 -240, doi:10.1016/0040-1951(94)00171-5.
Appel, P., A. Möller, and V. Schenk (1998), Highpressure granulite facies metamorphism in the Pan-African belt of eastern Tanzania: P-T-t evidence against granulite formation by continent collision, J. Metamorph. Geol., 16, 491-509, doi:10.1111/j.1525-1314.1998.00150.x.

Bagnall, P. S. (1963), The geology of the North Pare Mountains, Bull. Geol. Surv. Tanganyika, 10, 7-16. 
Bauer, W., R. J. Thomas, and J. Jacobs (2003), Proterozoic-Cambrian history of Dronning Maud Land in the context of Gondwana assembly, in Proterozoic East Gondwana: Supercontinent Assembly and Breakup, edited by M. Yoshida, B. F. Windley, and S. Dasgupta, Geol. Soc. Spec. Publ., 206, $247-$ 269

Beyth, M., D. Avigad, H. U. Wetzel, A. Matthews, and S. M. Berthe (2003), Crustal exhumation and indications for Snowball Earth in the East African Orogen: North Ethiopia and east Eritrea, Precambrian Res., 123, 187-201, doi:10.1016/S03019268(03)00067-6.

Bingen, B., et al. (2007), Crustal architecture in the Mozambique Belt, northeastern Mozambique: Perspective from $\mathrm{U}-\mathrm{Pb}$ geochronology and $\mathrm{Lu}-\mathrm{Hf}$ isotopes in zircon, paper presented at 7th International Symposium on Applied Isotope Geochemistry, Int. Assoc. of Geochem., Stellenbosch, South Africa.

Blasband, B., S. White, P. Brooijman, H. De Boorder, and W. Visser (2000), Late Proterozoic extensional collapse in the Arabian-Nubian Shield, J. Geol. Soc., 157, 615-628.

Burg, J. P., J. Van Den Driessche, and J. P. Brun (1994), Syn- to post-thickening extension in the Variscan Belt of western Europe: Modes and structural consequences, Geol. Fr., 3, 33-51.

Cadoppi, P., M. Costa, and R. Sacchi (1987), A cross section of the Namama Thrust belt (Mozambique), J. Afr. Earth Sci., 6, 493-504, doi:10.1016/08995362(87)90090-X.

Collins, A. S., and S. A. Pisarevsky (2005), Amalgamating eastern Gondwana: The evolution of the Circum-Indian orogens, Earth Sci. Rev., 71, 229 270, doi:10.1016/j.earscirev.2005.02.004.

Collins, A. S., T. Razakamanana, and B. F. Windley (2000), Neoproterozoic extensional detachment in central Madagascar: Implications for the collapse of the East African Orogen, Geol. Mag., 137, 39-51, doi: $10.1017 / \mathrm{S} 001675680000354 \mathrm{X}$.

Coolen, J. J. M. M., H. N. A. Priem, E. A. T. Verdurmen, and R. H. Verschure (1982), Possible zircon U-Pb evidence for Pan-African granulite-facies metamorphism in the Mozambique Belt of southern Tanzania, Precambrian Res., 17, 31-40, doi:10.1016/ 0301-9268(82)90152-8.

Costa, M., G. Ferrara, R. Sacchi, and S. Tonarini (1992), Rb/Sr dating of the Upper Proterozoic basement of Zambesia, Mozambique, Geol. Rundsch. 81, 487-500, doi:10.1007/BF01828611.

Costa, M., P. Cadoppi, R. Sacchi, and C. M. Fanning (1994), U-Pb "SHRIMP" dating of zircons from Mozambique gneiss, Boll. Soc. Geol. Ital., 113 $173-178$.

De Waele, B., J.-P. Liégeois, A. A. Nemchin, and F. Tembo (2006), Isotopic and geochemical evidence of Proterozoic episodic crustal reworking within the Irumide Belt of south-central Africa, the southern metacratonic boundary of an Archaean Bangweulu Craton, Precambrian Res., 148, $225-$ 256, doi:10.1016/j.precamres.2006.05.006.

Dewey, J. (1988), Extensional collapse of orogens, Tectonics, 7, 1123-1139, doi:10.1029/TC007i006p01123.

de Wit, M. J., S. A. Bowring, L. D. Ashwal, L. G Randrianasolo, V. P. I. Morel, and R. A. Rambeloson (2001), Age and tectonic evolution of Neoproterozoic ductile shear zones in southwestern Madagascar, with implications for Gondwana studies, Tectonics, 20, 1-45, doi:10.1029/2000TC900026.

Engvik, A. K., and S. Elvevold (2004), Pan-African extension and near-isothermal exhumation of a granulite facies terrain, Dronning Maud Land, Antarctica, Geol. Mag., 141, 649-660.

Engvik, A. K., E. Tveten, B. Bingen, G. Viola, M. Erambert, P. Feito, and S. de Azavedo (2007), PT-t evolution and decompressional textures of Pan-African high-pressure granulites, Lurio Belt, northeastern Mozambique, J. Metamorph. Geol., 25(9), 935-952, doi:10.1111/j.1525-1314.2007. 00736.x
Fossen, H. (2000), Extensional tectonics in the Caledonides: Synorogenic or postorogenic?, Tectonics, 19 , 213-224, doi:10.1029/1999TC900066.

Fritz, H., V. Tenczer, C. A. Hauzenberger, E. Wallbrecher, G. Hoinkes, S. Muhongo, and A. Mogessie (2005) Central Tanzanian tectonic map: A step forward to decipher Proterozoic structural events in the Eas African Orogen, Tectonics, 24, TC6013, doi:10.1029/ 2005 TC001796.

Grantham, G. H., M. Maboko, and B. M. Eglington (2003), A review of the evolution of the Mozambique Belt and implications of the amalgamation and dispersal of Rodinia and Gondwana, in Proterozoic East Gondwana: Supercontinent Assembly and Breakup, edited by M. Yoshida, B. F. Windley, and S. Dasgupta, Geol. Soc. Spec. Publ., 206, $401-425$.

Grantham, G. H., P. H. Macey, B. A. Ingram, M. P. Roberts, R. A. Armstrong, T. Hokada, K. Shiraishi, C. Jackson, A. Bisnath, and V. Manhica (2008), Terrane correlation between Antarctica, Mozambique and Sri Lanka: Comparison of geochronology, lithology, structure and metamorphism and possible implications for the geology of southern Africa and Antarctica, in Geodynamic Evolution of East Antarctica: A Key to the East-West Gondwana Connection, edited by M. Satish-Kumar et al., Geol. Soc. Spec. Publ., in press.

Hanson, R. E. (2003), Proterozoic geochronology and tectonic evolution of southern Africa, in Proterozoic East Gondwana: Supercontinent Assembly and Breakup, edited by M. Yoshida, B. F. Windley, and S. Dasgupta, Geol. Soc. Spec. Publ., 206, $427-$ 463.

Harley, S. L. (2003), Archaean-Cambrian crustal development of East Antarctica: Metamorphic characteristics and tectonic implications, in Proterozoic East Gondwana: Supercontinent Assembly and Breakup, edited by M. Yoshida, B. F. Windley, and S. Dasgupta, Geol. Soc. Spec. Publ., 206, 203-230.

Holmes, A. (1951), The sequence of Pre-Cambrian orogenic belts in South and Central Africa, in Proceed ings of the 18th International Geological Congress, edited by K. S. Sandford and F. Blondel, pp. 254 269, Assoc. des Serv. Géol. Afr., London.

Houseman, G., and P. England (1993), Crustal Thickening versus lateral expulsion in the Indian-Asian continental collision, J. Geophys. Res., 98, 12,23312,249, doi:10.1029/93JB00443.

Jacobs, J., and R. J. Thomas (2002), The Mozambique belt from an East Antarctic perspective, in Antarctica at the Close of a Millenium: Proceedings Volume 8th International Symposium on Antarctic Earth Sciences, edited by J. A. Gamble et al., Bull. R. Soc. N. Z., 35, 3-18.

Jacobs, J., and R. J. Thomas (2004), Himalayan-type indenter-escape tectonics model for the southern part of the late Neoproterozoic-early Paleozoic East African-Antarctic orogen, Geology, 32, 721-724, doi: $10.1130 / \mathrm{G} 20516.1$

Jacobs, J., W. Bauer, and C. M. Fanning (2003), Late Neoproterozoic/Early Palaeozoic events in central Dronning Maud Land and significance for the southern extension of the East African Orogen into East Antarctica, Precambrian Res., 126, 27-53, doi:10.1016/S0301-9268(03)00125-6.

Jacobs, J., B. Bingen, R. J. Thomas, W. Bauer, M. Wingate, and P. Feitio (2008), Early Paleozoic orogenic collapse and voluminous late-tectonic magmatism in Dronning Maud Land and Mozambique: Insights into the partially delaminated orogenic root of the East African-Antarctic Orogen?, in Geodynamic Evolution of East Antarctica: A Key to the East-West Gondwana Connection, edited by M. Satish-Kumar et al., Geol. Soc. Spec. Publ., in press.

Jamal, D. (2005), Crustal evolution in NE Mozambique: Implications for Gondwana reconstruction, Ph.D. thesis, Univ. of Cape Town, Cape Town, South Africa.

Johnson, P. R., and B. Woldehaimanot (2003), Development of the Arabian-Nubian Shield: Perspec- tives on accretion and deformation in the northern East African Orogen and the assembly of Gondwana, in Proterozoic East Gondwana: Supercontinent Assembly and Breakup, edited by M. Yoshida, B. F. Windley, and S. Dasgupta, Geol. Soc. Spec. Publ., 206, 289-325.

Johnson, S. P., T. Rivers, and B. De Waele (2005), A review of the Mesoproterozoic to early Palaeozoic magmatic and tectonothermal history of southcentral Africa: Implications for Rodinia and Gondwana, J. Geol. Soc., 162, 433-450, doi:10.1144/ 0016-764904-028.

Johnson, S. P., B. De Waele, D. Evans, W. Banda, F. Tembo, J. A. Milton, and K. Tani (2007), Geochronology of the Zambezi Supracrustal Sequence, southern Zambia: A record of Neoproterozoic divergent processes along the southern margin of the Congo craton, J. Geol., 115, 355-374, doi:10.1086/512757.

Jourde, G., and Y. Vialette (1980), La chaîne du Lurio (Nord Mozambique). Un témoin de l'existence de chaînes Kibariennes (800-1350 Ma) en Afrique Orientale, open file report, 75 pp., Bur. de Rech. Géol. et Min., Orléans, France.

Jung, S., and K. Mezger (2003), Petrology of basementdominated terranes: I. Regional metamorphic T-t path from $\mathrm{U}-\mathrm{Pb}$ monazite and $\mathrm{Sm}-\mathrm{Nd}$ garnet geochronology (Central Damara Orogen, Namibia), Chem. Geol., 198, 223-247, doi:10.1016/S00092541(03)00037-8.

Jung, S., K. Mezger, and S. Hoernes (2001), Trace element and isotopic $(\mathrm{Sr}, \mathrm{Nd}, \mathrm{Pb}, \mathrm{O})$ arguments for a mid-crustal origin of Pan African garnet-bearing Stype granites from the Damara Orogen (Namibia), Precambrian Res., 110, 325-355, doi:10.1016/ S0301-9268(01)00175-9.

Kröner, A. (2001), The Mozambique belt of East Africa and Madagascar: Significance of zircon and $\mathrm{Nd}$ model ages for Rodinia and Gondwana supercontinent formation and dispersal, S. Afr. J. Geol., 104, 151-166, doi:10.2113/1040151.

Kröner, A., R. Sacchi, P. Jaeckel, and M. Costa (1997), Kibaran magmatism and Pan-African granulite metamorphism in northern Mozambique: Single zircon ages and regional implications, J. Afr. Earth Sci., 25, 467-484, doi:10.1016/S0899-5362(97) 00117-6.

Kröner, A., B. F. Windley, P. Jaeckel, T. S. Brewer, and T. Razakamanana (1999), New zircon ages and regional significance for the evolution of the PanAfrican orogen in Madagascar, J. Geol. Soc., 156, 1125-1135, doi:10.1144/gsjgs.156.6.1125

Lenoir, J.-L., J.-P. Liégeois, K. Theunissen, and J. Klerkx (1994), The Palaeoproterozoic Ubendian shear belt in Tanzania: Geochronology and structure, $J$. Afr Earth Sci., 19, 169-184, doi:10.1016/08995362(94)90059-0.

Maboko, M. A., N. A. I. M. Boelrijk, H. N. A. Priem, and E. A. T. Verdurmen (1985), Zircon U-Pb and biotite $\mathrm{Rb}-\mathrm{Sr}$ dating of the Wami River granulites, eastern granulites, Tanzania: Evidence for approximately $715 \mathrm{Ma}$ old granulite-facies metamorphism and final Pan-African cooling approximately $475 \mathrm{Ma}$ ago, Precambrian Res., 30, 361-378, doi:10.1016/0301-9268(85)90088-9.

Macey, P. H., et al. (2007), Map explanation of sheets Alto Molócuè, 1537. Murrupula, 1538. Nampula, 1539. Mogincual, 1540. Errego, 1637. Gilé (1638) and Angoche (1639-40), Natl. Dir. of Geol. Maputo, Mozambique.

Meert, J. G. (2003), A synopsis of events related to the assembly of eastern Gondwana, Tectonophysics, 362, 1-40, doi:10.1016/S0040-1951(02)00629-7.

Melezhik, V. A., A. B. Kuznetsov, A. F. Fallick, R. A Smith, I. M. Gorokhov, D. Jamal, and F. Catuane (2006), Depositional environments and an apparent age for the Geci meta-limestones: Constraints on the geological history of northern Mozambique, Precambrian Res., 148, 19-31, doi:10.1016/j. precamres.2006.03.003. 
Möller, A., K. Mezger, and V. Schenk (2000), U-Pb dating of metamorphic minerals: Pan-African metamorphism and prolonged slow cooling of high pressure granulites in Tanzania, East Africa, Precambrian Res., 104, 123-146, doi:10.1016/ S0301-9268(00)00086-3.

Muhongo, S. (1994), Neoproterozoic collision tectonics in the Mozambique Belt of East Africa: Evidence from the Uluguru mountains, Tanzania, J. Afr. Earth Sci., 19, 153-168, doi:10.1016/08995362(94)90058-2.

Muhongo, S., and J.-L. Lenoir (1994), Pan-African granulite-facies metamorphism in the Mozambique Belt of Tanzania: U-Pb zircon geochronology, J. Geol. Soc., 151, 343-347, doi:10.1144/gsjgs. 151.2.0343.

Nédélec, E., E. W. Stephens, and A. E. Fallick (1995), The Pan-African stratoid granites of Madagascar: Alkaline magmatism in a post-collisional extensional setting, J. Petrol., 36, 1367-1391.

Norconsult Consortium, (2007a), Mineral resources management capacity building project, Republic of Mozambique; component 2: Geological infrastructure development project, geological mapping lot 1; sheet explanation, Rep. B6.f., 32 sheets, scale 1:250,000, 778 pp. + annexes, Natl. Dir. of Geol., Maputo, Mozambique.

Norconsult Consortium, (2007b), Mineral resources management capacity building project, Republic of Mozambique; component 2: Geological Infrastructure Development Programme, geophysical interpretation (lot 1), Rep. B4, 146 pp., Natl. Dir. of Geol., Maputo, Mozambique.

Pimental, M. M., A. F. Reinhardt, and N. F. Botelho (1999), Granites and the geodynamic history of the Neoproterozoic, Brasilia Belt, central Brazil: A review, Precambrian Res., 46, 463-483.
Pinna, P. (1995), On the dual nature of the Mozambique Belt, Mozambique to Kenya, J. Afr. Earth Sci., 21 477-480, doi:10.1016/0899-5362(95)00077-7.

Pinna, P., and P. Marteau (1987), Carta geologica de Moçambique, scale 1:1,000,000, with explanatory notes, Inst. Naç. de Geol., Maputo, Mozambique.

Pinna, P., G. Jourde, J. Y. Calvez, J. P. Mroz, and J. M. Marques (1993), The Mozambique Belt in northern Mozambique; Neoproterozoic $(1100-850 \mathrm{Ma})$ crustal growth and tectogenesis, and superimposed Pan-African $(800-550 \mathrm{Ma})$ tectonism, Precambrian Res., 62, 1-59, doi:10.1016/0301-9268(93) 90093-H.

Ring, U., A. Kröner, and T. Toulkeridis (1997), Palaeoproterozoic granulite-facies metamorphism and granitoid intrusions in the Ubendian-Usagaran Orogen of northern Malawi, east-central Africa, Precambrian Res., 85, 27-51, doi:10.1016/S03019268(97)00028-4.

Sacchi, R., J. M. Marques, M. Costa, and C. Casati (1984), Kibaran events in the southernmost Mozambique belt, Precambrian Res., 25, 141-159, doi:10.1016/0301-9268(84)90030-5.

Sacchi, R., P. Cadoppi, and M. Costa (2000), Pan-African reactivation of the Lurio segment of the Kibaran Belt system: A reappraisal from recent age determinations in northern Mozambique, J. Afr. Earth Sci. 30, 629-639, doi:10.1016/S0899-5362(00)00042-7.

Sommer, H., A. Kröner, C. A. Hauzenberger, S. Muhongo, and M. T. D. Wingate (2003), Metamorphic petrology and zircon geochronology of high-grade rocks from the central Mozambique Belt of Tanzania; crustal recycling of Archean and Paleoproterozoic materials during the Pan-African orogeny, J. Metamorph. Petrol., 21, 915-934.

Stern, R. J. (1994), Arc assembly and continental collision in the Neoproterozoic East African Orogen:
Implications for the consolidation of Gondwanaland, Annu. Rev. Earth Planet. Sci., 22, 319-351.

Tucker, R. D., L. D. Ashwal, M. J. Handke, M. A Hamilton, M. Le Grange, and R. A. Rambeloson (1999), U-Pb geochronology and isotope geochemistry of the Archean and Proterozoic rocks of northcentral Madagascar, J. Geol., 107, 135-153, doi: $10.1086 / 314337$

Unrug, R. (1992), The supercontinent cycle and Gondwana assembly: Component cratons and the timing of suturing events, J. Geodyn., 16, 215-246, doi:10.1016/0264-3707(92)90011-G.

Unrug, R. (1997), Rodinia to Gondwana: The Geodynamic Map of Gondwana Supercontinent assembly, GSA Today, 7, 1-6.

Vrána, S., V. Kachlík, A. Kröner, D. Marheine, A. V. Seifert, V. Zácek, and J. Baburek (2004), Ubendian basement and its late Mesoproterozoic and early Neoproterozoic structural and metamorphism overprint in northeastern Zambia, J. Afr. Earth Sci., 38 , 1-21, doi:10.1016/j.jafrearsci.2003.09.001.

Yoshida, M., J. Jacobs, M. Santosh, and H. M. Rajesh (2003), Role of Pan-African events in the CircumEast Antarctic Orogen of East Gondwana: A critical overview, in Proterozoic East Gondwana: Supercontinent Assembly and Breakup, edited by M. Yoshida, B. F. Windley, and S. Dasgupta, Geol. Soc. Spec. Publ., 206, 57-75.

B. Bingen, I. H. C. Henderson, M. A. Smethurst, and G. Viola, Geological Survey of Norway, N-7491 Trondheim, Norway. (giulio.viola@ngu.no)

S. de Azavedo, National Directorate of Geology of Mozambique, Nampula, Mozambique.

R. J. Thomas, British Geological Survey, Keyworth, NG12 5GG, UK. 